\title{
Definição de candidaturas parlamentares e relações entre chefes partidários no Brasil monárquico: o caso da participação de Zacarias de GóiseVasconce- los em eleições na Província do Paraná (1861-1862)
}

\author{
Sandro Aramis Richter Gomes* \\ Universidade Federal do Paraná
}

Curitiba - Paraná - Brasil

Este artigo comporta uma investigação sobre as articulações políticas que resultaram no lançamento das candidaturas do bacharel baiano Zacarias de Góis e Vasconcelos (1815-1877) a deputado geral pela província do Paraná, nos anos de 1861 e 1862. O presente estudo, portanto, consiste em uma análise acerca das implicações da ausência de regras precisas para o relacionamento entre os membros das instâncias administrativas dos partidos monárquicos. No Paraná dos anos 1860, as principais implicações dessa ausência eram a ingerência de lideranças nacionais doPartidoLiberal sobre processos de definição decandidaturasparlamentaresea neutralização do poder da elite política provincial. De outra parte, é evidenciado que a ingerência de lideranças nacionais na dinâmica eleitoral da província também inibia olançamento de candidaturaspeloPartidoConservador.Nessequadro,demonstra-sequeos desígnios eleitorais de líderes nacionais do Partido Liberal, no princípio dos anos 1860, limitaram a autonomia das lideranças paranaenses da agremiação no tocante aos modos de gestão desse partido.

\section{Palavias-chave}

Eleições; Elites políticas; Brasil monárquico; Província do Paraná.

* Doutorado em História pela Universidade Federal do Paraná (2017). E-mail: argomes8@gmail.com. 


\section{Definition of parliamentary candidates and relations between leaders of political parties in Empire of Brazil: the case of participation of Zaca- rias de Góis e Vasconcelos in elections of Province of Paraná (1861-1862)}

Sandro Aramis Richter Gomes

Universidade Federal do Paraná

Curitiba - Paraná - Brasil

This article contains an investigation into the political discourse that resulted in the launch of applications of bachelor Zacarias de Góis e Vasconcelos (1815-1877) the general deputy of Paraná Province in the years 1861 and 1862. This study therefore contains an analysis about the implications of the absence of precise rules for the relationship between the members of the bodies of the parties. Parana 1860s, the main results were the interference of national Liberal Partyleaders about setting processes of parliamentary candidates and neutralizing the power of provincial political elite. On the other hand, it is shown that the interference of national leaders in the provincial electoral dynamics also inhibited the release of applications by the Conservative Party. In this context, it demonstrates that the electoral interests of national leaders of Liberal Party, in the early 1860s, limited the political autonomy of provincial leaders of this party.

Elections; Political elites; Empire of Brazil; Province of Paraná. 


\section{Introdução}

Neste artigo é empreendida uma análise sobre as eleições para o cargo de deputado geral ocorridas na província do Paraná, nos anos de 1861 e 1862. Nessas ocasiões, o candidato vencedor foi o bacharel baiano Zacarias de Góis eVasconcelos (1815-1877), quefora presidente da referida província entre os anos de 1853 e 1855 . O objetivo fundamental desse estudo é evidenciar aspectos da influência de chefes partidários nacionais sobre a vida política das províncias do Império. Por conseguinte, busca-se salientar as limitações daautonomiaedopoderpolíticodoslíderespartidáriosprovinciais em um contexto anterior à reorganização dos diretórios nacionais e provinciais dos partidos Conservador e Liberal. A reorganização dos diretórios do Partido Conservador principiou em 1867. 'A reorganização administrativa do Partido Liberal, por seu turno, ocorreu em $1868 .^{2}$

1 Nessa oportunidade, o diretório nacional do partido adotou o nome de Centro da União Conservadora. Os diretórios provinciais assumiram a denominação de Grêmios. Os diretórios municipais, por sua vez, eram denominados de Juntas. A respeito da reorganização dos diretórios do Partido Conservador a partir de 1867, ver BANDECCHI, Pedro Brasil. Bases da União Conservadora e os Estatutos do Grêmio Paulistano e os primórdios do movimento republicano em São Paulo. Revista do Instituto de Estudos Brasileiros, São Paulo, n. 14, p. 149-158, 1973.

2 Nesse contexto de reorganização administrativa, o diretório nacional do Partido Liberal assumiu a denominação deCentro Liberal.Contudo, na historiografia não há ênfase para o estudo da mudança nas regras atinentes à administração do partido. Antes, verifica-se maior inclinação para a análise das propostas políticas elaboradas pelas lideranças nacionais do Partido Liberal no momento em que houve a reorganização dos diretórios dessa agremiação. A principal fonte para o estudo das características e desdobramentos dessa reorganização é o jornal A Reforma, editado na capital do Império. A análise das edições desse periódico permite destacar que um dos principais efeitos da reorganização do diretório nacional do Partido Liberal foi implantar a regularidade de reuniões da Mesa Executiva. Ao mesmo tempo, tal reorganização favoreceu uma comunicação mais assídua e regrada entre o diretório nacional e os diretórios provinciais do partido. Em geral, essa comunicação era referente aos resultados eleitorais das províncias e aos episódios acontecidos no decorrer das eleições, tais como fraudes nas urnas. A semelhança entre os processos de reorganização dos diretórios conservadores e liberais reside no fato de que foram empreendidos em épocas nas quais as agremiações encontravam-sena oposição ao gabineteministerial. Acerca das propostas políticas concebidas pelos líderes nacionais do Partido Liberal no contexto da reorganização administrativa do partido, ver AMARAL, Roberto; BONAVIDES, Paulo. Textos políticos da História do Brasil. Volume II. 3. ed. Brasília: Senado Federal, 2002, p. 456-470. 
Desse modo, a homologação das candidaturas de Zacarias de Góis e Vasconcelos a deputadogeral pelo Paraná ocorreu em um contexto de baixa formalização da vida interna dos diretórios partidários provinciais. Essa baixa formalização implicava a ausência de regras precisas para a realização dos processos de lançamento de candidaturas. Ao mesmo tempo, não existiam limites precisos para a interferência dos diretórios nacionais sobre as atividades dos diretórios provinciais. Portanto, ao longo deste artigo argumenta-se que essa ausência de limites permitiu ao diretório nacional do Partido Liberal conduzir o processo de homologação de candidaturas à Câmara dos Deputados no Paraná, nos anos de 1861 e 1862.

No curso deste artigo são fundamentais três argumentos. Primeiro, demonstra-se que, no princípio dos anos 1860, havia marcante influência do governo provincial do Paraná nas eleições para deputado geral. Tratase, pois, de um indício da restrição da autonomia dos chefes partidários da província naquele contexto. Existiam eventuais recusas a apoiar candidatos lançados pelo presidente da província do Paraná. Essas recusas, porém, não eramsuficientesparauniroscorreligionáriosemtornodenomesalternativos às candidaturas oficiais. A desunião dos correligionários permitia que o governo provincial incorporasse membros dos partidos Conservador e Liberal aos seus projetos eleitorais.

Segundo, demonstra-sequeolançamentodecandidaturasapoiadaspor políticosnacionais, noâmbito da província do Paraná, era acatado pelos chefespartidáriosprovinciais.Nessequadro,competesalientarqueaslideranças nacionais do Partido Liberal neutralizavam, ainda que circunstancialmente, a influência dos dirigentes partidários da província.

Terceiro, argumenta-se que, no Paraná dos anos 1860, a oficialização de candidaturas apoiadas por dirigentes partidários nacionais inibia o lançamento das mesmas pelo Partido Conservador. Nesse contexto, tal agremiação encontrava-se em oposição ao gabinete ministerial. Dessa forma, a candidatura única era uma consequência das dificuldades de os líderes políticos provinciais impedirem a ingerência de chefes partidários de projeção nacional na dinâmica eleitoral da província. 
O desenvolvimento desses argumentos é realizado por meio da análise de informações veiculadas em órgãos de imprensa editados, no início dos anos 1860, nas cidades de Curitiba, Paranaguá, Rio de Janeiro e São Paulo.

Este artigo é desenvolvido em três etapas. Na primeira etapa é demonstrado que, no princípio dos anos 1860, o diretório nacional do Partido Liberalexercia ostensiva interferênciana definiçãodecandidaturasparlamentares em distintas províncias. Portanto, a operacionalidade desta etapa do artigo reside em evidenciar que a neutralização das ambições políticas dos correligionários liberais nas províncias não era umacontecimento incomum no limiar dos anos 1860 . Trata-se, assim, de salientar o marcante envolvimento dos dirigentes nacionais do partido na escolha de candidatos.

Nasegundaetapasãoanalisadas ascondições políticasqueviabilizaram a eleição de Zacarias de Góis a deputado geral pelo Paraná no ano de 1861. Nesse âmbito, é destacado que o apoio do gabinete ministerial era crucial para o êxito eleitoral de um candidato à Câmara dos Deputados. O candidatoescolhido pelogabinete recebia oapoio da elite política provincial.Porém, tal apoio era apenas circunstancial, visto que não se desdobrava em sólida aliança política. Ao mesmo tempo, esse apoio não implicava o comprometimento do candidato eleito com demandas formuladas por setores da elite provincial. O caso da atuação política de Zacarias de Góis na política paranaense permiteevidenciarocaráterprotocolarda performanceparlamentar de um político adventício.

Naterceira etapa doestudoéressaltadaainterferência deumaliderança nacional do Partido Liberal para viabilizar a reeleição de Zacarias de Góis a deputado geral em 1862. Dessa forma, cumpre demonstrar que nessa oportunidadehouveaneutralizaçãodaspretensõeseleitoraisdemembrosdaelite política provincial. Nessesentido, integrantes dos partidos Conservadore LiberaldoParanáeximiram-sededisputarumaeleiçãocontraumcandidatode projeção nacional que angariara apoio de uma liderança política do Império.

Neste artigo, a categorização de Zacarias de Góis como um político de projeçãonacionaléfundamentada pelofato de que, àépoca desua reeleição para deputado geral pelo Paraná, ele integrava o grupo de lideranças políti- 
cas que fundou a Liga Progressista. Por consequência, esse bacharel acomodou-sena condição de dirigente nacional da Liga. Após o retorno dos liberais à oposição ao gabinete ministerial, em 1868, Góis participou da gestão do diretório nacional do Partido Liberal.

No momento de sua primeira eleição a deputado geral pelo Paraná, em 1861,Zacarias de Góis era um político integrado aos mecanismos de nomeações para cargos comissionados da administração imperial. Sua integração começou ainda na década de 1840 quando, em 1845, foi nomeado presidente da província do Piauí. Em 1852, ele foi investido no cargo de ministro da Marinha, no contexto da vigência do gabinete ministerial presidido por Joaquim José Rodrigues Torres (1812-1872), futuro Visconde de Itaboraí. ${ }^{3}$

$$
* * *
$$

Cumpre ressaltar que a consecução das três etapas doartigoéorientada pelo propósito de produzir um conhecimento acerca de um tema pouco desenvolvido na historiografia brasileira - as relações entre as elites imperiaise as elites provinciais no âmbito da gestão dos partidos políticos. Em síntese, a historiografiacarecedeumaagenda depesquisaquefavoreçaa produçãode um conhecimento acerca da natureza das atividades dos diretórios partidários ao tempo dolmpério. Assim, oestudorespeitanteaosmodelos degestão partidária, às formas de resolução de conflitos no interior dos diretórios e às condiçõesderelacionamentoentreasinstânciasdaadministraçãopartidária nãopertencemaocontemporâneoroldasinvestigaçõesacercadapolíticado Brasil oitocentista.

Nesse sentido, há semelhanças entre os estudos históricos, em distintos contextos, a respeito da vida partidária nacional. Em suma, as linhas de força dosestudos sobreos partidosmonárquicossãomarcadas pela construção de amplos panoramas sobre a composição social dessas agremiações. Cabe salientar,também, a ênfaseconferida pela historiografiaàabordagemacerca

3 Acerca da trajetória política de Zacarias de Góis, ver OLIVEIRA, Cecília Helena Salles (Org.). Zacarias de Góis e Vasconcelos. São Paulo: Editora 34, 2002; VENÂNCIO FILHO, Alberto (Org.). Zacarias de Góis e Vasconcelos. Brasília: Edição da Câmara dos Deputados, 1979. 
dopensamentodaslideranças dessasagremiações. ${ }^{4}$ Deoutrolado, constatase nesses estudos a orientação para a análise circunscrita à atividade política dos expoentes dos partidos monárquicos. ${ }^{5}$ Tais estudos têm propiciadoa compreensão sobre a natureza e os desdobramentos de crises políticas que envolviam os próceres dos partidos. ${ }^{6}$

Nahistoriografia, as informações acerca da atividade política de dirigentes partidários nacionais permanecem centrais para a compreensão sobre a vida interna das instituições imperiais. Porém, não há avanços no entendi-

4 Para o conhecimento das linhas de força sobre a vida partidária do Brasil monárquico, ver, CARVALHO, José Murilo de. A construção da ordem: a elite política imperial/Teatro das sombras: a política imperial. 3. ed. Rio de Janeiro: Civilização Brasileira, 2007; CHACON, Vamireh. História dos partidos brasileiros. Brasília: Editora da UnB, 1981; COSTA, Emília Viotti da. Da Monarquia à República: momentos decisivos. 8. ed. São Paulo: Ed. da Unesp, 2007; FAORO, Raymundo. Os donos do poder: formação do patronato político brasileiro. 8. ed. São Paulo: Globo, 1989; FRANCO, Afonso Arinos de Melo. História e teoria dos partidos políticos no Brasil.SãoPaulo:Alfa-Ômega, 1974; GOUVÊA, Maria de Fátima Silva. O Império das províncias: Rio de Janeiro, 1822-1889. Rio de Janeiro: Civilização Brasileira, 2008; MATTOS, Ilmar Rohloff de. O tempo Saquarema. São Paulo: Hucitec, 1986; MOTTA, Rodrigo Patto Sá. Introduçãoà história dos partidos políticos brasileiros. Belo Horizonte: Editora da Universidade Federal de Minas Gerais, 1999; ROETT, Riordan. Brazil: Politics in a Patrimonial Society. New York: Praeger Publichers, 1984.

5 Acerca dos recentes estudos sobre a dinâmica política do Império brasileiro, ver ESTEFANES, Bruno Fabris. Conciliar o Império: Honório Hermeto de Carneiro Leão, os partidos e a política de Conciliação no Brasil monárquico (1842-1856). Dissertação (Mestrado em História Social). Faculdade de Filosofia, Letras e Ciências Humanas, Universidade de São Paulo, São Paulo, 2010; HÖRNER, Erik. Partir, fazer e seguir: apontamentos sobre a formação dos partidos e participação política no Brasil da primeira metade do século XIX. In: MARSON, Isabel Andrade; OLIVEIRA, Cecília Helena Salles de. Monarquia, Liberalismo e Negócios no Brasil: 1790-1860. São Paulo: Edusp, 2013, p. 213-240; NASCIMENTO, Carla Silva do. OBarão de Cotegipe e a crise do Império. Dissertação (Mestrado em História). Centro de Ciências Humanas e Sociais, Universidade Federal do Estado do Rio de Janeiro, Rio de Janeiro, 2012; NEEDELL, Jeffrey. The party of order: the conservatives, the State, and slavery in the Brazilian monarchy. Stanford: Stanford University, 2006; RIBEIRO, Filipe Nicoletti. Império das incertezas: política e partidos nas décadas finais da monarquia brasileira (1868-1889). Dissertação (Mestrado em História Social). Faculdade de Filosofia, Letras e Ciências Humanas, Universidade de São Paulo, São Paulo, 2015.

6 Nesse quadro, compete destacar o estudo de Sérgio Ferraz respeitante aos fatores da dissolução da Câmara dos Deputados e dos Gabinetes Ministeriais no decorrer do Segundo Reinado. FERRAZ, Sérgio Eduardo. O Império revisitado: Poder Moderador, Câmara dos Deputados e instabilidade ministerial (1840-1889). Tese (Doutorado em Ciência Política). Faculdade de Filosofia, Letras e Ciências Humanas, Universidade de São Paulo, São Paulo, 2012. 
mentoacercadascaracterísticaseimpactosdainserçãodessesdirigentesnas decisões das unidades provinciais dos partidos monárquicos.

Aomesmotempo,aproduçãodeanálisesacercadaatividadepolíticadas elitesprovinciaisnaépocadolmpérionãopropiciouaconstruçãodeumentendimentosobreofuncionamentodospartidosnoâmbitoprovincial.Essasanálises contribuemparaacompreensãoacercadasatividadesdeinstituiçõescomoas AssembleiasLegislativas,edaatuaçãodaselitesprovinciaisemagênciascomo oParlamentodolmpério. ${ }^{7}$ Essesestudospossibilitam, ainda,oconhecimento atinente às formas de relacionamento entre elites provinciais e imperiais. ${ }^{8}$

Por conseguinte, na historiografia contemporânea verifica-se a carência de uma reflexão concernente à organização interna dos partidos monárquicos no âmbito das províncias. Por consequência, permanece pouco desenvolvidaainvestigaçãorespeitanteàsaliançaseembatesmantidospelas elites provinciais comchefes partidários demaiorprojeção política.Mais precisamente, remanesce pouco avançada a tarefa de investigar as formas pelas quais esses embates interferiam na autonomia administrativa dos diretórios provinciais dos partidos monárquicos.

Por outro lado, a literatura acerca de eleições no Brasil do Segundo Reinado permanece dedicada ao estudo das regras capitais do funcionamento

7 DOLHNIKOFF, Miriam. O pacto imperial: origens do federalismo no Brasil. São Paulo: Globo, 2005; FREITAS, Ana Paula Ribeiro. Minas e a Política Imperial: reformas eleitorais e representação política no Parlamento brasileiro (1853-1863). Tese (Doutorado em História Social). Faculdade de Filosofia, Letras e Ciências Humanas, Universidade de São Paulo, São Paulo, 2015; OLIVEIRA, CarlosEduardoFrança de.Construtores doImpério, defensores da província:SãoPauloeMinas Gerais na formação do Estado Imperial e dos poderes locais, 1823-1834. Tese (Doutorado em História Social). Faculdade de Filosofia, Letras e Ciências Humanas, Universidade de São Paulo, São Paulo, 2014.

8 MARTINS, Maria Fernanda Vieira. A velha arte de governar: uma abordagem sobre elites políticas a partir do Conselho de Estado (1842-1889). Rio de Janeiro: Arquivo Nacional, 2007. 
dos pleitos. ${ }^{9}$ Presentemente, umavanço noestudo sobreas eleiçõesno Brasil oitocentistaconsistenainvestigaçãosobreanaturezadalegislaçãoeleitoral. ${ }^{10}$

Em verdade, tais discussões desconsideram a existência de diretórios partidários. Tal desconsideração implica, por exemplo, o desconhecimento sobre as formas de relacionamento entre as elites provinciais e imperiais no contexto de eventos como os pleitos eleitorais. ${ }^{11}$ Assim, a análise sobre os limites da autonomia política das elites provinciais e da natureza das atribuiçõesdosdirigentespartidáriosnacionaismantém-sepoucodesenvolvidona historiografia brasileira.

Cabe salientar que, no início dos anos 2000, Jeffrey Mosher advogara a pertinência de uma renovação na abordagem sobre os partidos do Brasil monárquico. Em resumo, Mosher salientou que a historiografia não encarava os partidos como instituições dotadas de regras formais. Dessa forma, era imperioso desenvolver análise que propiciasse uma inovação em relação às investigações acerca de modos informais de relações políticas, a exemplo da constituição deredes declientela peloschefes partidários.Porém, a consecução dessa perspectiva de análise permanece inconclusa. ${ }^{12}$

9 Ver CAVALCANTI, Themístocles Brandão. O voto distrital no Brasil. Rio de Janeiro: Editora da Fundação Getúlio Vargas, 1975; KINZO, Maria Dalva Gil. Representação política e sistema eleitoral no Brasil. São Paulo: Edições Símbolo, 1980; NICOLAU, Jairo. Eleições no Brasil: do Império aos dias atuais. Rio de Janeiro, Zahar, 2012; PORTO, Walter Costa. O voto no Brasil: da Colônia à $6^{\text {a }}$ República. Rio de Janeiro: Topbooks, 2002.

10 LIMONGI, Fernando. Revisitando as eleições do Segundo Reinado: manipulação, fraude e violência. Lua Nova, São Paulo, n. 91, p. 51-113, 2014.

${ }^{11}$ Acerca de propostas contemporâneas para a elaboração de uma agenda de estudos sobre os partidos imperiais, ver DANTAS, Mônica Duarte. Partidos, liberalismo e poder pessoal: a política no Império do Brasil. Um comentário ao artigo de Jeffrey Needell, Formação dos partidos políticos no Brasil da Regência à Conciliação, 1831-1857. Almanack Braziliense, São Paulo, n. 10, 2009, p. 40-47; NEEDELL, Jefrey D. Formação dos partidos políticos no Brasil da Regência à Conciliação, 1831-1857. Almanack Braziliense, São Paulo, n. 10, 2009, p. 5-22; NEEDELL, Jeffrey D. Formação dos partidos brasileiros: questões de ideologia, rótulos partidários, lideranças e prática política, 1831-1888. Almanack Braziliense, São Paulo, n. 10, 2009, p. 54-63; SALLES, Ricardo. Notas de um debate: Comentários sobre o texto de Jeffrey Needell Formação dos partidos políticos no Brasil da Regência à Conciliação, 1831-1857. Almanack Braziliense, São Paulo, n. 10, 2009, p. 48-53.

12 MOSHER,JeffreyC.Politicalmobilization, partyideology, andlusophobiainnineteenth-century Brazil: Pernambuco, 1822-1850. Hispanic American Historical Review, vol. 80, n. 4, p. 881-912, 2000. 
Porconseguinte,cumpresalientarorestritodesenvolvimentodeestudos atinentesaosprocessoseleitoraisemâmbitoprovincial.Essesestudosconferiram maior atenção a ocorrências inerentes aos pleitos, tais comoafraudenas urnas. ${ }^{13}$ De fato, essa abordagem é operacional para o conhecimento acerca da cultura política do Brasil oitocentista. Os estudos atinentes a esse tema também propiciam um conhecimento acerca do perfil social dos votantese das condições de participação política. ${ }^{14}$ Porém, a compreensão sobre a vida administrativa dos partidos em um contexto eleitoral do Brasil monárquico não recebeu acurada análise.

Nesse sentido, permanece incipiente o entendimento sobre a natureza dos conflitos de interesses políticos que surgiam em uma agremiação partidária no contexto da definição de candidaturas a instituições como a Câmara dos Deputados. Verifica-se, pois, uma restrita ênfase na compreensão das eleições do Brasil monárquico como acontecimentos no quais ocorriam multifacetadas interações entre os gestores das instâncias da administração partidária.

Em síntese, busca-se evidenciar que, no início dos anos 1860, a influência de chefes partidários nacionais sobre o lançamento de candidaturas parlamentares no Paraná decorreu da baixa formalização da vida interna

Para o conhecimento acerca da investigação desenvolvida por este autor respeitante à vida político-partidária de uma província do Império - Pernambuco - no contexto da primeira metade do século XIX, ver MOSHER, Jeffrey C. Political Struggle, Ideology and the State Building: Pernambuco and the construction of Brazil, 1817-1850. Lincoln: University of Nebraska Press, 2008.

${ }^{13}$ Ver: GRAHAM, Richard. Clientelismo e política no Brasil do século XIX. Rio de Janeiro: Editora da Universidade Federal do Rio de Janeiro, 1997.

14 Acerca de estudos sobre a relação entre a estrutura populacional ea vida política das províncias, ver CARDOSO, Jayme Antônio. A população votante deCuritiba (1853-1881).Dissertação (Mestradoem História). Setor de Ciências Humanas, Letras e Artes, Universidade Federal do Paraná, Curitiba, 1974; CARDOSO, Jayme Antônio. Essai d'utilisation des listes electorales dansl'étude dela population du Paraná (Brésil) vers 1870. Tese (Doutorado em História). École des Hautes Études en Sciences Sociales, Paris, 1977; FARIA, Vanessa Silva de.Oprocesso dequalificação de votantes no Brasillmpério: perfil da população votante no distrito sede de Juiz de Fora, Minas Gerais (1872-1876). Dissertação (Mestrado em História). Instituto de Ciências Humanas e Sociais, Universidade Federal de Ouro Preto, Mariana, 2011; NUNES, Neila Ferraz Moreira. A experiência eleitoral em Campos dos Goytacazes (1780-1889): frequência eleitoral e perfil da população votante. Dados, Rio de Janeiro, v. 46, n. 2 , p. 311-343, 2003. 
dos diretórios. Mais especificamente, é salientado que não existiam limites definidosacerca dascompetências dos diretóriosnacionais dospartidosmonárquicos. Essa carência de limites, por um lado, permitiu a homologação, em 1861, da candidatura de Zacarias de Góis a deputado geral pelo Partido Conservador do Paraná. Ela permitiu, ainda, a reeleição desse bacharel pelo Partido Liberal paranaense, no ano seguinte. A baixa formalização das atividades dos diretórios resultou, naquele contexto, na ausência de regras para o relacionamento entre os membros dos diretórios provinciais e dos diretórios nacionais dos partidos. Assim, no curso das três etapas do artigo é fundamentado o argumento segundo o qual, naquela época, o lançamento de candidaturas parlamentares, em distintas províncias, não era realizado por meio de previsíveis ritos.

O diretório nacional do Partido Liberal e as formas de oficialização de candidaturas parlamentares no início dos anos 1860

Afinalidadeelementardesteestágiodoartigoédemonstraroargumento de que não eram apenas os dirigentes liberais do Paraná que tinham sua autonomia política reduzida em virtude da interferência dos chefes nacionais do partido em processos de definição de candidaturas parlamentares. Asinformaçõesempregadasnestaseçãoevidenciamanaturezacentralizada desses processos. As informações são concernentes a episódios da história eleitoral da província do Rio de Janeiro.

De forma diferente em relação ao caso do Paraná, havia ocasiões em que os liberais fluminenses tornavam públicas as suas críticas aos dirigentes daagremiação.Nessequadro,competesalientarqueosvocábulosconsistório e sinagoga eram utilizados na época em referência ao diretório nacional do Partido Liberal, sediado na cidade do Rio de Janeiro. Essa utilização era uma forma de destacar que as deliberações do partido eram comandadas por um 
seleto grupo.Contudo, Centro Diretor era a denominação oficial do diretório nacional dessa agremiação. ${ }^{15}$

\section{$* * *$}

Em 1863, houve a interferência do diretório nacional do Partido Liberal no processo de definição dos candidatos a deputado geral pelo $2^{\circ}$ distrito eleitoral da Província do Rio de Janeiro. Este distrito correspondia à região de Campos dos Goytacazes. Tal interferência foi criticada pelo redator do jornalconservadorConstitucional,emeditorial publicadoa03desetembrodo mencionado ano.

Esse editorial evidencia que os indivíduos que mantinham uma relação próxima com os chefes do Partido, tais como o advogado carioca Francisco Otaviano de Almeida Rosa (1825-1889), possuíam maiores condições de terem as suas candidaturas homologadas. Portanto, os gestores do diretório nacional controlariam o partido de modo a impedir a igualdade nas formas decompetiçãointernaentreospretendentesadeterminadoscargoseletivos:

Odirectorio liberal, consistório, synagoga, ou como melhor nome elugar haja, declarouterassentadoosnomesprestigiosos paracandidatosdo $2^{\circ}$ districtocom o fim de arredar os muitos pretendentes. Ou fosse por isso ou fosse para despachar o círculo da corte, o certo é que arrumaram o Sr. Valdetaro para o $2^{\circ}$ districto.Maso que dirão os pretendentes taboqueados peranteo prestígio de outro feliz candidato, o Sr. Luiz Pereira? Eis aí um nome prestigioso! De toda a população do Rio de Janeiro apenas aqueles quem leem os anúncios dos jornais sabem que o Sr. Pereira é um aprendiz de advocacia do escriptorio do Sr. [Francisco] Octaviano [então deputado geral pelo Rio de Janeiro]. Esses leitores de anúncios podem, pois, explicar o enigma do prestígio do Sr.Pereira. Tudoissofoiumaverdadeira prestidigitaçãoquesóaos profanos deveráterembasbacado.Dizemquecerto candidato contentou-secoma promessa deoutra promoção: nesse tempo não vão estar as frutas passadas. Ao Sr. Lima Campos declararamquesecontentasseeternamentecomaassembleia provincial, para desenferrujar os pulmões, que, verdade é, andam sempre bem azeitados. Ao Sr. Heredia..., desse falam à boca pequena, enquanto em público lisonjeiam o cabalista da cidade de Campos. Mas o que dirá o Sr. Almeida Barbosa, desterrado da chapa porfalta de prestígio? Preparou o terreno, venceu as eleições,

${ }^{15}$ CORREIO MERCANTIL, Rio de Janeiro, 30 de julho de 1863, n. 208, p. 1. 
segundo o directorio fez o seu dever, sed tulit alter honores [mas outro levou a glória]. ${ }^{16}$

Em junho de 1863, o jornal A Actualidade já admoestara a influência exercida pelos expoentes do Partido Liberal em processos de definição de candidaturas. Desse modo, as reflexões apresentadas pelo redator desse órgão de imprensa evidenciam que o princípio da década de 1860 foi marcado por expressiva ingerência política daqueles chefes. Por outro lado, o texto transcrito abaixo contém indícios de que houve formas de contestação ao modo pouco democrático e transparente pelo qual os líderes do diretório tomavam decisões.Ouseja, houveuma contestaçãoàlegitimidadedocontrole partidárioexercido poresseslíderes.Deoutra parte,essetextoevidenciaque o aumento da centralização das decisões por chefes partidários liberais era um dos resultados da criação da Liga Progressista:

Temos muito ouvido falar de directorio; posto que não o ousem fazer pela imprensa.Comoórgãoque somos de ideias liberais puras, temos direito, senão dever de chamar a terreiro essa potência das trevas, só conhecida por suas firmans e ukases, chamá-la vir à luz da imprensa exibir seus títulos. Se é um directorioliberalesse dequetodosfalam, essesquedizem ser reconhecidopor todoscomosupremoárbitroemmatériaeleitoral (concedendo, porhypothese, que no partido liberal tal centralização de força seja possível), se é liberal não deve temer a luz, nem esquivar-se à discussão da imprensa. [...] Tem o directorio liberal seus títulos baseados em direito divino? São os chefes do partido liberalchefes por serem quem são? No caso afirmativo, curvemo-nos humildes deixando passar a justiça d'El Rei. Ou são esses chefes tão poderosos não por graça divina, mas por aclamação dos povos? Neste caso, mostre-nos a acta do grandecolégioqueosnomeou supremoseleitores doimpérioealiviemo povo da mais que pesada tarefa de uma comédia eleitoral. Nem uma, nem outra coisa. O direito divino!... Mas há muito tempo que à divindade não se imputa maisaresponsabilidadedetantosgovernosineptoscomoosdosreisfainéantse quejandos. Aaclamação dos povos!.... Ondee quandotevelugaro supremo comício que lhes deu a investidura? O directorio tem outra origem, ele é produto do enxerto que o partido liberal sofreu, é o resultado, o partido monstruoso da monstruosa aliança que deu-se há pouco tempo, Liga. [...] Quem há aí que ignore a maneira criminosa pela qual vai procedendo o directorio? Ocapricho, ointeressepessoal,eointeiroesquecimentodamissãoquesemnenhum direito

${ }^{16}$ CONSTITUCIONAL, Rio de Janeiro, 03 de setembro de 1863, n. 118, p. 2. Grifos no original. 
se encarregou, eis os vergonhosos conselheiros de que se cerca. ${ }^{17}$

No ano de 1863, houve, na província do Rio de Janeiro, uma divergência entre os correligionários do Partido Liberal em virtude da ingerência do diretório central do partido, o qual era comandado pelo mineiro Teófilo Benedito Otoni (1807-1869), acerca da escolha decandidatos a deputadogeral. Conferir atenção a um relato sobre essa divergência possibilita demonstrar que os membros do diretório central buscavam controlar a homologação de candidaturas à Câmara dos Deputados em distintas províncias.

Em um texto veiculado no Diário do Rio de Janeiro, em agosto de 1863, o advogado Nicolau Rodrigues dos Santos França e Leite (1803-1867), deputado geral pela Paraíba em dois mandatos (1845-1847; 1848), criticava o fato de que olançamento das candidaturas liberais foi comandado apenas pelos principais membros do diretório central. Esse texto é, em verdade, uma Circular que Rodrigues enviou aos eleitores do $3^{\circ}$ distrito eleitoral da província do Rio de Janeiro, que abarcava o município de Niterói. Nessa ocasião, Rodrigues era candidato a deputado geral pelo Partido Liberal.

Nessa Circular, ele descreveu, inicialmente, um episódio a respeito do comportamentoeleitoraladotadopelosliberais dedaqueledistritoeleitoral. Esse comportamento consistiu em repudiar o modo pelo qual foram definidas as candidaturas a deputado geral naquela localidade. Nesse âmbito, Rodrigues informou que o diretório nacional do Partido Liberal organizou a lista dos candidatos às eleições daquele ano na província do Rio de Janeiro sem consultar os correligionários da agremiação.

A referida Circular tem o propósito de sustentar o argumento de que existia uma exacerbada centralização de decisões no Partido Liberal. Ao mesmo tempo, ela comportava a ideia de que os eleitores precisavam de liberdade de voto. Por fim, nessa Circular é argumentado que era necessário haver clareza e lisura no processo de definição de candidaturas. Em suma, por meio da leitura desse texto é evidenciado que, no início dos anos 1860, houve, em um distrito eleitoral do Rio de Janeiro, uma reação pública à prá-

${ }^{17}$ A ACTUALIDADE, Rio de Janeiro, 13 de junho de 1863, n. 443, p. 1. Grifos no original. 
tica de imposição de candidatos pelo diretório nacional do Partido Liberal. Essa reação não foi realizada pela imprensa. Antes, foi suscitada por um correligionário do partido. Leia-se, pois, o seguinte excerto da Circular de Rodrigues:

Srs. Eleitores - Dirigindo-me a vós, principiarei por lembrar-vos de factos recentes que se tem passado diante de nós. Havia a Pátria, jornal de Nictheroy, logo depois da dissolução da câmara dos Srs. Deputados [12 de maio de 1863], denunciado ao público uma reunião secreta de alguns ex-deputados e senadores, no qual se proclamaram eles diretores geares da eleição do partido liberal e formularam então a lista dos nomes daqueles de seus afeiçoados, que deviam por vós ser eleitos. [...] Em uma reunião, a única pública que houve na corte, a do teatro de S. Januário, por ocasião de um orador, o Sr. Dr. Queirós, referir-se a ordens do suposto diretório, o Exmo. Sr. Zacarias declarou que o directorio não dava ordens, mas somente conselhos, e o Exmo. Sr.T. B. Ottoni acrescentouqueessesconselhossóseriamdadosquandofossemconsultadosou pedidos. Isto passou no dia 7 de agosto corrente, antevéspera das eleições. Os candidatos, animados porestasexplícitas declarações, continuaramajustificar suas candidaturas diante do corpo eleitoral, único a quem compete o legítimo julgamento.Ascoisassepassavam destemodo, quandoaparece,comsurpresa, uma ordem do oculto directorio, impondo ao corpo eleitoral da Corte e província do Rio de Janeiro nomes de candidatos de sua afeição, vontadeabsoluta, ciência certa e plenos poderes! A esta exposição de verdadeiro despotismo, de explícita significação de que - quero e mando - se apressou o corpo eleitoral da freguezia de Sant'Anna da corte, dessa freguezia respeitável para o partido liberal, por nela se ter como refugiado a liberdade nos tempos difíceis, onde nunca o poder insano dos nossos mandantes pode abater esses espíritos grandes e heroicos, esta freguezia se apressou, repetimos, a manifestar a sua desaprovação a semelhante arbítrio, e dando a mais severa lição a esse directorio, a essa entidade, que se escondia para surpreender depois, mostrou que o corpo eleitoral desta freguezia era composto de homens livres, e que sabiam, por si, e pelos ditames de suas consciências, apreciar os serviços, o caráter e habilitações daqueles que nunca tinham desmentido suas convicçõese contrariado seus princípios liberais, foram procurar o respeitável e venerando magistrado, o Exmo. Sr. Chichorro da Gama, e oferecer-lhes os seus votos, em prêmio dos seus serviços ao partidoliberal, eem compensaçãoàs perseguições deque por isso tem sido vítima. ${ }^{18}$

18 DIÁRIO DO RIO DE JANEIRO, Rio de Janeiro, 30 de agosto de 1863, n. 237, p. 3. 
Nessa Circular, Rodrigues defendeu que o Brasil precisava inspirar-se no modelo eleitoral de países como os Estados Unidos e a Inglaterra. Segundo o autor do texto, a transparência e liberdade na escolha de candidatos eram decisivas para incentivar a mobilização popular nas eleições, ou seja, era necessário tornar a vida eleitoral mais dinâmica e democrática. No seu entendimento, tal dinamismo e democracia eram inexistentes na vida política do Brasil:

Neste momento não posso deixar de tributar aos ilustres cavalheiros os mais sinceros votos de respeito e admiração. Senhores. Na Inglaterra, a mestra do governo parlamentar, por ocasião de eleições, por toda parte se levantam reuniõespopulares(meetings), nessasreuniões, queseformamportodooreino,os candidatos do distrito aparecem, os ministros mesmo que não candidatos não são dispensados de comparecer; e aí oram ao povo, fazem sua profissão de fé política, recebem os aplausos, ou os mais explícitos sinais de repulsa, ouvem todas as increpações [sic] que se fazem à sua conduta, aos seus erros políticos, os insultos mesmo muitas vezes não lhe são dispensados. [...] Nos Estados Unidos acontece o mesmo, e o mesmo acontece hojeem Portugal, e sereis vós, Srs. Eleitores do $3^{\circ}$ distrito do Rio de Janeiro, que fareis abnegação da vossa própria dignidade e da vossa própria consciência para vos tornardes meros condutores dechapas, compostas das afeições, davontadeedasconveniências alheias? $^{19}$

Apesardesseapeloaoseleitores do $3^{\circ}$ distritoeleitoral fluminense, Nicolau Rodriguesnãofoieleito.Nessa oportunidade,oscandidatos vitoriososno distrito foram omédico Joaquim Manuel de Macedo(281 votos), oadvogado José Fernandes Moreira (252 votos) e o militar Frederico Carneiro de Campos (243 votos). ${ }^{20}$ Os eleitos eram ligados ao Partido Liberal. A votação final de Rodrigues não foi informada na imprensa. Contudo, no Colégio Eleitoral deNiteróieleobtevesomentesetesufrágios-a sétima votação daquelecolégio dentre os nove candidatos ali sufragados. ${ }^{21}$

Verifica-se, portanto, que a ausência de apoio de lideranças partidárias era um fator que contribuía para a derrota eleitoral de um candidato, no

19 Loc. Cit. Grifo no original.

20 DIÁRIO DO RIO DE JANEIRO, Rio de Janeiro, 12 de setembro de 1863, n. 249, p. 1.

21 DIÁRIO DO RIO DE JANEIRO, Rio de Janeiro, 10 de setembro de 1863, n. 247, p. 1. 
contexto do Segundo Reinado. A tentativa de contornar essa falta de apoio por meio da aproximação com o eleitorado não era uma estratégia eficaz. Por outro lado, a ausência das regras acerca da participação das lideranças políticas nacionais sobre a administração dos diretórios nas províncias era umfatordedescontentamentodoscorreligionários.Emgeral,haviaocasiões nasquaisos correligionários demandavammaiortransparêncianas decisões partidárias acerca da escolha de candidatos. Esses correligionários também condenavam a imposição de candidaturas por políticos que controlavam o diretório nacional do Partido Liberal.

Vinculação ao partido governista e êxito eleitoral:

a primeira eleição de Zacarias de Góis a deputado geral pelo Paraná (1861)

A partir desta seção do artigo é ressaltada a baixa formalização da vida interna do Partido Liberal do Paraná. Demonstra-se que uma das consequências implicadas na baixa formalização era a ausência de precisos critérios para a definição de candidaturas e para o relacionamento com o diretório nacional do partido. Em virtude dessa ausência instalou-se uma situação na qual o partido, no âmbito da província do Paraná, tornou-se mais suscetível à ingerência de lideranças nacionais da agremiação.

Nesse contexto, os chefes partidários paranaenses não possuíam destacada participação no cenário político nacional. Essa participação tornou-se mais significativa a partir de meados dos anos 1860, quando integrantes da elite provincial passaram a exercer cargos ministeriais. ${ }^{22}$ No decorrer dessa década, elestambém começaramainfluirnagestão deesquemas denomeaçõesimperiais.Dessaforma,caberessaltarqueobacharel paranaense Jesuíno Marcondes de Oliveira e Sá (1827-1903), do Partido Liberal, foi ministro da

22 Para o conhecimento da relação de políticos paranaenses que ocuparam cargos ministeriais e presidências de províncias ao tempo do Segundo Reinado, ver ALVES, Alessandro Cavassin. A Provínciado Paraná(1853-1889): a classe política, a parentela no Governo.Tese(Doutoradoem Sociologia). Setor de Ciências Humanas, Letras e Artes, Universidade Federal do Paraná, Curitiba, 2014. 
Agricultura, Comércio e Obras Públicas de 1864 a 1865. Nessa época, ele viabilizoua nomeaçãodeseteparentesparacargosdaadministraçãoimperial. ${ }^{23}$

O acesso de membros da elite paranaense a posições mais decisivas da vidapolíticanacionalfoicontemporâneoàreorganizaçãoadministrativados partidos monárquicos, ocorrida no fim dos anos 1860. Uma das implicações dessa reorganização foi permitir a participação mais decisiva e rotineira de membros daquela elite na vida interna dos diretórios nacionais dos partidos. Em 1869, por exemplo, o bacharel paranaense Manuel Francisco Correia (1831-1905), ministro dos Negócios Estrangeiros de 1871 a 1873, era o representante do diretório municipal de Paranaguá nas reuniões do diretório nacional do Partido Conservador. ${ }^{24}$

No âmbito do Partido Liberal, a reorganização do modelo de gestão de diretórios possibilitou uma comunicação mais assídua e regrada entre dirigentesprovinciaisenacionaisdaagremiação.Nessequadro,osdirigentesnacionaiseraminformadossobrelançamentodecandidaturaseodesempenho do partido em pleitos eleitorais. O bacharel Manuel Alves de Araújo (18361908), que comandou o Ministério da Agricultura em 1882, foi o interlocutor do diretório paranaense do Partido Liberal junto aos dirigentes nacionais da agremiação nos anos $1870 .^{25}$

A eleição de Zacarias a deputado geral pelo Paraná, em 1861, permitiu-o retornar à Câmara dos Deputados após uma ausência de cinco anos. Em 1856, ele não tivera êxito em sua candidatura a deputado geral pelo $6^{\circ}$ círculo eleitoral da Bahia. ${ }^{26}$ Nesse sentido, a sua candidatura pelo Paraná consistiu em um projeto apoiado pelo governo provincial.

Houve, portanto, uma mobilização de agentes ligados ao gabinete ministerial, tais como o presidente da província, em defesa da viabilização de

\footnotetext{
23 JORNAL DO COMMERCIO, Rio de Janeiro, 04 de janeiro de 1866, n. 4, p. 1.

24 DEZENOVE DE DEZEMBRO, Curitiba, 30 de janeiro de 1869, n. 963, p. 2-3.

25 GAZETA DE NOTÍCIAS, Rio de Janeiro, 04 de dezembro de 1876, n. 335, p. 1.

26 DIÁRIO DO RIO DE JANEIRO, Rio de Janeiro, 15 de dezembro de 1856, n. 356, p. 1.
} 
sua eleição pelo Paraná. Compete salientar, assim, que o estudo das eleições de Zacarias a deputado geral pelo Paraná permite o conhecimento sobre as formas deapoio conferidas poraltosagentes da administração imperial para reabilitar politicamente indivíduos pertencentes ao grupo partidário governista.

De outra parte, a eleição de Zacarias a deputado geral em 1861 não consiste em um indício da construção de aliança com os chefes conservadores da província. ${ }^{27}$ Ao contrário, ele teve como principal correligionário o então presidente de província, o bacharel José Francisco Cardoso (1830-1885), o qual era originário de uma parentela pertencente à elite social do município fluminensedeltaguaí.Osmembrosdessa parentelaeramintegrantesdoPartido Conservador. ${ }^{28}$

$\mathrm{Na}$ ocasião em que recebeu tal apoio, Zacarias ainda pertencia a esse partido, do qual se desvincularia no início da década de 1860. Em seguida, ingressou na Liga Progressista. De acordo com o jornal A Ordem, antes de pertencer à Liga, Zacarias era um opositor da proposta de criar tal agremiação. Leia-se, pois, o seguinte comentário publicado nesse periódico:

Pode-se ficar acima das paixões políticas para que se não as veja, ou abaixo para que se não as sinta: em dois partidos políticos se divide actualmente $o$ Brasil,havendouma pequenafracçãoqueasimesma denominaprogressista.A qual destes partidos, porém, pertencerá o conselheiro Zacarias? Conservador puro até um certo tempo, conciliador até 1860 , tempo em que alimentava as mais belas esperanças, conservador puro até meados de 61, tempo em que alcançou umacadeiranarepresentaçãonacional pormerofavordosseusamigos de então, hoje diz pertencer à liga. Depois de S. Exc. a ter combatido o grupo, queentãoselevantava na câmara temporária, com uma arrogância pueril,sem prever que suas belas palavras não se esquecem facilmente, foi fazer parte, e tornar-seumdosvultosmaisproeminentesdessanovafracção,que,momentos antes, olhara com desdém. Estaalternativa deopiniões, estas combinações po-

27 Nas ocasiões em que Zacarias de Góis apresentou-se candidato a deputado geral pelo Paraná, estava em vigor a Lei dos Círculos (1855-1875), a qual implantou o voto distrital no Brasil. Ao tempo das candidaturas de Zacarias, o Paraná possuía somente um distrito eleitoral.

${ }^{28}$ MOREIRA, Gustavo Alves Cardoso. Uma família no Império do Brasil: os Cardoso de Itaguaí (um estudo sobre economia e poder). Dissertação (Mestrado em História). Instituto de Ciências Humanas e Filosofia, Universidade Federal Fluminense, Niterói, 2005. 
líticas em que S. Exc. a Parecia entrar por mero brinco, fizeram com que alguns de seus mandantes, duvidando da sinceridade de suas crenças, e vendo que nãopodiam combatercontraaquelesquenãotinham recebidoovotopopular, deixassem de comparecer ao colégio eleitoral [do Paraná, em 1862]. ${ }^{29}$

Portanto, quando de sua primeira eleição a deputado geral pelo Paraná, em 1861, Zacarias ainda se beneficiava do fato de pertencer a uma agremiação que controlava ogabinete ministerial.Tal pertencimento foi decisivo para a sua vitória na aludida eleição.

A eleição do então conservador Zacarias de Góis àquele cargo ocorreu em uma época na qual lideranças políticas nacionais exerciam notável influência sobre a gestão dos partidos monárquicos no Paraná. Tal influência gerava, porvezes, a insatisfação de dirigentes partidários provinciais. Porém, esses líderes não possuíam a força política necessária para impedir a eleição de candidatos apoiados pelo gabinete ministerial. Essa influência, em 1861, permitiu a eleição de outro adventício para o cargo de deputado geral. Tratava-se do médico baiano Joaquim Inácio Silveira da Motta (1818-1891).

Em síntese, a eleição de Zacarias e Silveira da Motta enfrentara reações contrárias no Paraná. Contudo, o apoio do governo da província e do gabinete ministerial garantiu a vitória dos referidos candidatos. Na época, o gabinete era comandado por Ângelo Moniz da Silva Ferraz (1812-1867), do Partido Conservador. ${ }^{30}$

Conforme um órgão da imprensa conservadora, uma das formas de conseguir o sucesso eleitoral desses candidatos era por intermédio do apoio do governo provincial. Um dos aspectos desse apoio consistia em atribuir cargos públicos aos correligionários dos candidatos governistas. Conforme demonstrado neste artigo, no contexto do Partido Liberal do Paraná a não obtençãodecargoscomissionadospeloscorreligionáriosdocandidatooficial era passível de gerar uma celeuma. Essa celeuma ocasionava, por exemplo, a mudança no comando partidário.

29 A ORDEM, São Paulo, 18 de agosto de 1862, n. 12, p. 1. Grifos no original.

30 Acerca dos episódios da eleição para duas vagas de deputado geral ocorrida no Paraná em 1861, ver DEZENOVE DE DEZEMBRO, Curitiba, 30 de janeiro de 1869, n. 963. 
Atente-se, assim, ao modo por meio do qual o redator de A Ordem referiu-se à estratégia empregada pelo presidente José Francisco Cardoso para viabilizar a eleição de seus candidatos a deputado geral (Zacarias de Góis e Joaquim Silveira da Motta):

Na ânsia de chegar ao fim, na terrível dúvida em que se achava s. ex. [o presidentedaprovíncia], recorreuao meioheroicoquesoemempregarosgovernos perdidos [...]. Abriu-se o cofre provincial, criou-se empregos, deu-se gratificações,fez-se promessas sem conta eo santuário da autoridade converteu-seem um escritório mercantil em que a mercadoria era o voto, e o estipêndio o suor do povo. ${ }^{31}$

A votação dos candidatos a deputado geral pelo Paraná em 1861 foi publicadapelojornalDezenovedeDezembro,emabrildesseano.Atente-seàs informações apresentadas no seguinte Quadro:

Quadro I

Resultado da eleição para duas vagas de deputado geral

(Província do Paraná, 1861)

\begin{tabular}{|c|c|c|c|}
\hline Nome & Profissão & Partido & Votos \\
\hline Joaquim Inácio Silveira da Motta & Médico & Conservador & 114 \\
\hline Zacarias de Góis e Vasconcelos & Advogado & Conservador & 107 \\
\hline Jesuíno Marcondes de Oliveira e Sá & Advogado & Liberal & 85 \\
\hline José Mathias Ferreira de Abreu & Advogado & Conservador & 49 \\
\hline Laurindo Abelardo de Brito & Advogado & Liberal & 6 \\
\hline Manuel Francisco Correia & Advogado & Conservador & 4 \\
\hline José Inácio Silveira da Motta & Advogado & Liberal & 3 \\
\hline Luiz Francisco da Câmara Leal & Advogado & Conservador & 1 \\
\hline José Antônio de Camargo e Araújo & Padre & Liberal & 1 \\
\hline
\end{tabular}

Fonte: DEZENOVE DE DEZEMBRO, Curitiba, 27 de abril de 1861, n. 319, p. 1.

31 A ORDEM, São Paulo, 18 de agosto de 1862, n. 12, p. 2. 
Essa eleição ocorreu em um contexto no qual não existia a exigência da inscrição prévia de candidaturas. ${ }^{32}$ Portanto, eram contabilizados como votos válidos os sufrágios destinados a indivíduos que não se apresentavam como candidatos. No pleito ocorrido na província Paraná em 1861, os cinco indivíduosmenosvotadosnãohaviam selançadocomo pretendentesauma vaga na Câmara dos Deputados.

Essa eleição aconteceu em um período de pouca formalização da vida interna dos partidos. Assim, não existiam na época ritos precisos para o lançamentodecandidaturas.Afaltadenormasconsistentessobreadefiniçãode candidaturasimpunhaobstáculosparaqueoscorreligionáriosdeumpartido permanecessem unidose disciplinados na tarefa deelegeros candidatos oficiais da agremiação. Porconsequência, havia a possibilidade de serem lançadas candidaturas dissidentes.

Nesse âmbito, a eleição de 1861 no Paraná evidenciou a ausência de um processoregradoeconsensualsobreadefiniçãodecandidaturaspeloPartido Conservador. Naquele pleito, estavam, de um lado, os candidatos conservadores apoiados pelo governo provincial (Joaquim Silveira da Motta e Zacarias de Góis). De outro lado, estava o candidato conservador que matinha relações mais sólidas com a elite provincial (José Mathias Ferreira de Abreu).

Na época em que Zacarias candidatou-se pela segunda veza deputado geral pelo Paraná, em 1862, a imprensa ainda comentava - e admoestava o modo como sua primeira vitória fora conquistada. A esse respeito, note-se queumórgãodeimprensaligadoaoPartidoLiberal,oCommerciodoParaná, mostrou-se contrário à reeleição de Zacarias. Esse jornal era editado na cidade de Paranaguá, situada no litoral do Paraná.

Nesse quadro, o redator do periódico buscou rememorar as causas da primeira eleição de Zacarias a deputado geral pelo Paraná. A interferência do governo provincial foi operacional à vitória eleitoral desse bacharel em

32 A respeito das mudanças nas regras de organização das eleições no Brasil, ver NICOLAU, Jairo. Eleições no Brasil... Op. cit. 
1861. A concessão de benesses a apoiadores desse candidato era apontada como o motivo central dessa vitória. O excerto reproduzido a seguir evidencia que a inserção de Zacarias no jogo eleitoral do Paraná obteve o apoio do gabinete ministeriale, por conseguinte, do Governo do Paraná. Esses apoios inviabilizaram a vitória de uma liderança local do Partido Liberal, a saber, o citado bacharel Jesuíno Marcondes de Oliveira e Sá:

O ilustrado redator do Correio Mercantil parece pretender mostrar que a província esteve isenta quequalquer influência estranha, ou presidencial;nós não somosinteiramenteopostosàintervençãodogovernoemeleições,entendemos mesmoqueele deve procurar fazera vitória pender paraolado deseusamigos, sem que altere de modo algum a escolha do povo, sem que esqueça nunca a sua alta missão, para descer ao campo da luta e sofrer as inventivas dos contendores. Para contestar, porém, as palavras de que usa o Mercantil, não é preciso maisdoquecitarumtópicodacartadocorrespondentedoCommerciodoParaná, quedepoisdealgumasconsideraçõesarespeitodareeleiçãodoconselheiroZacarias diz:"Todos sabemos quanto custou à moralidade pública para a eleição de 1860 apontar um, dois três votos sobre o Sr. Sr. Jesuíno a favor do Sr. conseIheiroZacarias. Consultai o voto actual da província, sem empenho, sem oferta e garantia de postos e de hábitos, ante uma derrota parlamentar e a expressão symbolica vos responderá que tenho razão hoje, e que ainda mais razão tive quando, na carta última, deixei escapar uma ideia vaga sobre as pretensões

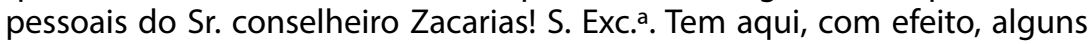
amigosdedicados, masestesestãoagrilhoadospoliticamentepelosoficiosos." ${ }^{\prime \prime 3}$

De outra parte, um indício das dificuldades enfrentadas por chefes partidários paranaenses na eleição de 1861 à Câmara dos Deputados em face da candidatura de Zacarias é evidenciado nas seguintes considerações do correspondente do Diário do Rio de Janeiro em Curitiba. Mais precisamente, asinformaçõesapresentadaspeloarticulistaconsistememevidênciasdeque antigas lideranças políticas da província não conseguiram suplantar a força da candidatura de Zacarias.

Emtaisconsiderações, verifica-sequetantoos conservadorescomoosliberaisqueselançaram candidatoseramopositores doentãochefe doexecu-

${ }^{33}$ A ORDEM, São Paulo, 18 de agosto de 1862, n. 12, p. 2 
tivo provincial. O Partido Conservador, ao qual Zacarias pertencia na época, não se eximiu de lançar um candidato - o bacharel José Mathias Ferreira de Abreu (1816-1869). Dessa maneira, o princípio da inserção de Zacarias em processos eleitorais no Paraná encontrou resistências locais. Essas resistências, todavia, nãoforam suficientes paraimpediroêxito do antigo presidente da província:

É de lastimar que o Diário do Rio de Janeiro não possua um correspondente no Paraná.DevezemquandolápublicaocorrespondentedoJornaldoCommercio um aranzel em estilo bíblico em que eleva às nuvens a presidência do Sr. [José Francisco] Cardoso, pelo que por aqui sofre-se diariamente conhece a província por ser seu correspondente o elogiado, porque quem falará bem por aqui Sr. Cardoso senão o Sr. Cardoso? Já ficaram pelas costas as malditas eleições. Só em Paranaguá se tem de proceder a uma municipal, porque as primeiras foram anuladas, em virtude de ordens e contra ordens do Sr. Cardoso a índole paranaense é essencialmente pacífica; porque do contrário muito havia quelastimar-se,porqueseopresidentedizendoaoproprietáriodoDezenove[de Dezembro] quetinha força para ganhar a eleição, se demitindo todas as autoridades policiais enomeandoas ad rem, parecia quererbazofiar, assimnãoaconteceu, visto que excedeu na verdade a todos os cálculos de uma violência bem calculada. O resultado da eleição foi duplicado. A interferência do governo fez com que só dois candidatos Ihe resistissem, a saber, os Drs. Jesuíno Marcondes de Oliveira e José Mathias Ferreira de Abreu. Vendo o presidente que os não podia vencer, nem pela violência, porque as famílias desses cavalheiros possuemmuitosmembros, queespalhadospelosdiversoslugaresdaprovíncia têm relaçõesquenão podem ser destruídas porumgovernodedias, além disso têm amigos dedicados que por eles se interessavam e obrigaram o Sr.Cardoso a enviar forças para todos os pontos, recomendando que se não admitissem duplicatas, para que não tivessem sequer 50 votos os filhos da província. [...] Resultado que terá de ser examinado pela assembleia dos Srs. Deputados visto os fundamentos razoáveis das duplicadas de Paranaguá e Curitiba. O colégio eleitoralem Paranaguáestevetumultuoso, a imprudência de um subdelegado do Dr. Cardoso que gritou pela tropa ia dando lugar a sérios distúrbios. Ao Dr. Manuel Alves de Araújo se deve não ter havido sangue. O Dr. Laurindo, vendo a posiçãoquetomouo presidente, fezconvergiralguns votos paraseuscolegas Drs. Jesuíno Marcondes e Ferreira de Abreu. O Paraná se via na necessidade de enrolar as bandeiras dos partidos, porque a todos interessava guerrear e opor-se ao governo. ${ }^{34}$

34 DIÁRIO DO RIO DE JANEIRO, Rio de Janeiro, 28 de fevereiro de 1861, n. 58, p. 1. 
Segundo o redator de A Ordem, a vitória de Zacarias em 1861 ocorreu em uma época em que o presidente da província, o citado José Francisco Cardoso, buscava combatertanto os chefesliberais, quanto os chefesconservadores da província. A despeito de divergirem do presidente da província, osliberaiseconservadoresdoParanánãodesenvolveramaçãoconjuntapara inviabilizar o êxito eleitoral de Zacarias e de Silveira da Motta. A falta de unidade permitiuqueogoverno provincial cooptasseparao seu projetoeleitoral membros dos partidos Conservador e Liberal:

O governo, sem ter pensamento, sem ter ordem em suas ideias, sem procurar o apoio de uma opinião, uniu-se em Curitiba a um grupo sem denominação e sem crenças para combater liberais e conservadores em Antonina, Príncipe e Castro, a conservadores contra liberais em Paranaguá, Guaraqueçaba e Morretes a liberais contra conservadores. ${ }^{35}$

A eleição de Zacarias, portanto, foi beneficiada pela disposição de setores dos partidos monárquicos de colaborarem com os projetos políticos do gabinete e do Governo Provincial. Por conseguinte, a vitória eleitoral do bacharel baiano não gerou sua aproximação com os líderes da política paranaense.Aesserespeito,competemencionaroocasionalcontatoestabelecido entre Zacarias e personagens da elite política de Paranaguá após a sua posse como deputado geral.

Em 1862, por exemplo, ele manteve uma comunicação essencialmente protocolar com os membros Câmara Municipal de Paranaguá. Nessa época, essa instituição presidida pelo liberal Caetano de Souza Pinto (1819-1879). A menção a essa comunicação possibilita evidenciar o caráter anódino da atuação de Zacarias como deputado geral pelo Paraná. A eleição desse bacharel ao posto de deputado geral pelo Paraná, portanto, não ocasionou a sua incorporação à rotina da vida político-partidária da província. Antes, tal eleição foi decorrência de uma estratégia de próceres do Partido Liberal. A finalidade dessa estratégia era manter Zacarias politicamente ativo em um

35 A ORDEM, São Paulo, 18 de agosto de 1862, n. 12, p. 2. 
contexto imediatamente posterior ao malogro de sua passagem pela presidência do gabinete ministerial.

Em abril de 1862, às vésperas da nomeação de Zacarias para a presidênciadogabineteministerial,ocorridaemmaio,osvereadoresdeParanaguáencarregaram-no da tarefa de representar a instituição em uma cerimônia que ocorreria na Corte.Zacarias, que ainda exercia o mandato de deputado geral peloParaná,manifestou-sesobreasuainvestiduranaquelatarefaprotocolar:

Ilmos. Srs. Presidente e mais vereadores da cidade de Paranaguá - Honrados por VV. SS. Com a incumbência de representar essa municipalidade na inauguração da estátua equestre, votada à memória de D. Pedro I e de felicitar por semelhante motivo a S. M. o Imperador, cumprimos eu e meus colegas de comissão o nosso mandado pelo modo constante da inclusa felicitação, na qual procuramos ser fiel interpretes dos sentimentos de VV. SS. Estimando infinitamente que houvéssemos conseguido. Rio 22 de abril de 1862.Zacarias de Góes e Vasconcellos. ${ }^{36}$

Esse ofício evidencia, ainda, o limitado envolvimento de um parlamentar adventício em relação à vida política da província. Portanto, um dos elementos da atuação política de Zacarias como deputadogeral peloParanáera manter um relacionamento formal com lideranças partidárias locais e não se envolver nas rivalidades entre os setores da elite política da província.

No Paraná provincial, no início dos anos 1860, Zacarias desenvolveu uma atividade legislativa distanciada do contato com as bases e as lideranças eleitorais que o apoiaram. Em última analise, eram circunstanciais as relações entre o então deputado geral e os dirigentes partidários do Paraná. Competedemonstrar,noestágiosubsequentedesteestudo,queoafastamento de Zacarias do jogo político paranaense foi encarado pela imprensa como um acontecimento benéfico para a consolidação da autonomia da vida partidária provincial.

36 COMMERCIO DO PARANÁ, Paranaguá, maio de 1862, p. 3. 


\section{As lideranças nacionais do Partido Liberal e a eleição parlamentar}

\section{de 1862 no Paraná:}

\section{a neutralização de chefes partidários provinciais}

No contexto em que ocorreu a nomeação de Zacarias ao posto de presidente do Conselho de Ministros, a 24 de maio de 1862, houve uma comemoração em Curitiba. Por um lado, essa comemoração evidencia que esse bacharel teria partidários na província da qual foi presidente, sobretudo em Curitiba. Por outro lado, a sua nomeação implicou a convocação de nova eleição ao cargo de deputado geral pelo Paraná. A esse respeito, leia-se a seguinte informação extraída do Diário do Rio de Janeiro, de junho de 1862:

RecebemosoCorreioOfficial deCoritibaqueadianta até 6 do corrente.Odia 20 foi designado para eleição à vaga deixada pelo Sr. conselheiro Zacarias. "Esta folha, dando notícia da nomeação do ministério de 24 de Maio diz: "A mala tendo chegado no dia 3 a esta capital, trouxe a notícia da elevação ao ministério do deputado por esta província conselheiroZacarias de GóiseVasconcelos. Tão grata nova aos paranaenses os fez prorromper em significativas demonstrações de alegria. De todos os lados da cidade subiram aos ares foguetes; à noite uma banda de música, seguida por pessoas aliás muito gradas, tocando à porta dos mais distintos cidadãos. Essa pública eespontânea manifestaçãoé a prova mais exuberante das simpatias que tem sabido granjear deste povo 0 ilustre conselheiro"."37

Porém, uma vez que a duração do Gabinete Zacarias se limitou ao período entre os dias 24 e 30 de maio de 1862, esse bacharel apresentou-se candidato à vaga de deputado geral da qual havia abdicado. O retorno dos antigoscomponentes dessegabineteà CâmaradosDeputadoseraumprojeto dos chefes nacionais da Liga. Ou seja, tal projeto interferiu nas eleições de diferentes províncias. A esse respeito, o redator de A Ordem salientou:

Procurou-se mostrar a reeleição dos ministros decaídos como um dever de honra para as províncias que lhes tinham dado um diploma; não se estudou sua história, nem se indagou suas crenças. Olhou-se apenas ofato de representaruma província, sem atender se espontaneamentelhe deram o mandato ou

37 DIÁRIO DO RIO DE JANEIRO, Rio de Janeiro, 25 de junho de 1862, p. 1. 
se foram forçadas a isso. ${ }^{38}$

A interferência do gabinete comandado pelo Marquês de Olinda em possibilitar o retorno à Câmara dos Deputados de seus antigos membros, de 24 de maio, não teve sucesso em províncias como Pernambuco. No ano de 1862 , no âmbito do $3^{\circ}$ círculo eleitoral de Pernambuco, o candidato a deputado geral apoiado pelo gabinete ministerial era o bacharel Antônio Coelho de Sá e Albuquerque (1821-1868), que fora ministro da Agricultura de 24 a 30 de maio de 1862. A despeito do apoio do gabinete, Coelho foi derrotado pelo desembargador Álvaro Barbalho Uchôa Cavalcanti (1818-1889), membro do Partido Conservador. Naquele pleito à Câmara dos Deputados, Barbalho angariou 164 votos, enquanto Coelho obteve 138 sufrágios. ${ }^{39}$

Tal informação é um indício de que havia províncias menos suscetíveis à ingerência de lideranças partidárias nacionais. Nessas províncias, os chefes partidários e o eleitorado não encampavam, em todas as ocasiões, as candidaturasrecomendadaspelosdiretóriosnacionais.Enfim,oreferidoresultado eleitoral evidencia que uma diferença crucial entre as elites provinciais dizia respeito à maior ou menor capacidade de afrontarem as ordens e projetos eleitorais de chefes partidários nacionais.

Por outro lado, o estudo sobre o caso da reeleição de Zacarias a deputado geral pelo Paraná permite demonstrar que o poder político de chefes partidáriosnacionaisera empregado para unificarosesforços dos correligionários nas províncias em favor de um candidato. No Paraná dos anos 1860, as lideranças do Partido Liberal demonstravam não possuir uma estratégia eleitoral adequada para contrabalançar a ingerência dos chefes nacionais dessaagremiação.Porconseguinte, restavaaesseschefesprovinciaisapoiara candidatura imposta por dirigentes nacionais do partido. Conforme o jornal Constitucional:

Chamado que foi o conselheiro Zacarias para o Gabinete de 24 de Maio, tudo mudou aqui; e os próprios liberais que tão encarniçadamente o guerrearam

38 A ORDEM, São Paulo, 28 de julho de 1862, n. 9, p. 1.

39 DIÁRIO DO RIO DE JANEIRO, Rio de Janeiro, 18 de julho de 1862, n. 196, p. 1. 
foram pressurosos em angariar votos para o ministro de 6 dias. Esse fervor não era oculto a ninguém, e até se dizia que assim deviam obrar em prejuízo de qualquer outro [candidato], porque de S. Ex. tinha o Paraná tudo a esperar. Felizmente eu nunca pensei assim, e hoje mesmo creio que S. Ex. pelo Paraná nada fez. ${ }^{40}$

Essas considerações também dizem respeito ao problema do baixo envolvimento de adventícios dotados de maior projeção política na vida social dasprovínciaspelasquaisobtinhammandatos.Nocontextodesuareeleição, Zacariasjá estava integradoà Liga Progressista.Por consequência, as antigas lideranças do Partido Liberal do Paraná apoiaram a candidatura de Zacarias. Esseapoio,contudo,foideterminadoporumchefepolíticonacional-ocitado TeófiloBeneditoOtoni.Todavia, aimprensaqueseopunhaaogabineteministerial defendia que, no Paraná, os candidatos a esse pleito teriam de ser originários da província. Assim, o problema da interferência na autonomia política da provínciaera mencionado pelosopositores da candidatura deZacarias. Concernente a essa questão, leia-se o comentário do redator do jornal paranaenseintituladoPharol,oqualfoirepublicadonoperiódicopaulistaAOrdem:

Tratando deeleições, não podemos nosfurtarao deverdetranscreveralgumas linhas de um jornal literário, porém propenso às ideias liberais, o Pharol, que se publica no Paraná, tratando do ministério diz: "Perdidos os lugares que ocupavam certos ministros decaídos, na câmara temporária, uma escolha de tem de aparecer na actualidade que preencha as posições vagas. [...] Aproxima-se o dia 20 de Julho em que tem de ser eleito um deputado por esta província em consequência da vaga que deixou o Sr. Zacarias. Na sua reeleição se pensa, mas nós temos pressentimentos de que essa não se realizará por virtude de coisas quenão convêm desdejá dizer.Se pertencêssemos ao corpo eleitoral da província,ousetivéssemosinfluêncialegítimanoseiodele, noscomprometeríamos a apresentar e a recomendar os nomes de dois distintos paranaenses, os Srs. Drs. Manuel Alves de Araújo e Manuel Francisco Correia, para um deles preencher a vaga existente deixada pelo Sr. Zacarias. É esta uma confissão sincera que fazemos. São cousas sobre que não se pode ainda emitir um juízo seguro; mas todos aqueles que acompanharam o pleito eleitoral no Paraná [em 1861] e viram os vícios com que se achava a eleição que deu lugar ao Sr. Zacarias tomar parte na representação nacional, não poderão duvidar de que

40 CONSTITUCIONAL, Rio de Janeiro, 16 de fevereiro de 1864, n. 19, p. 2. 
a província não acolhe com agrado a candidatura do seu ex-presidente".41

Cumpre destacarque, no contexto dos anos 1860, houvemomentos em que os processos de homologação de candidaturas não opunham somente chefes partidários nacionais a chefes partidários provinciais. Antes, tais processossuscitavamoantagonismoentrechefesmunicipaisechefesprovinciais dos partidos. Esseantagonismo, por suavez, favorecia, noâmbitomunicipal, uma aproximação entre os conservadores e os liberais. Ou seja, tal antagonismo criava uma circunstancial aproximação entre políticos de menor projeção no cenário partidário.

O estudo de um episódio da história política paulista possibilita corroborar este argumento. De outra parte, o estudo sobre tal episódio evidencia que as lideranças do Partido Conservador, na referida década, também eram propensas a interferir na homologação de candidaturas. Dessa forma, oempregodométodocomparativonesteestágiodoartigotem porfinalidade evidenciar que, no princípio dos anos 1860, não era incomum a definição unilateral de candidaturas parlamentares.

Nesse contexto, a prática de definição unilateral de candidaturas não era uma prática adotada apenas por chefes partidários nacionais. Antes, dirigentes partidários das províncias também recorriam a esse expediente. Por conseguinte, a definição unilateral suscitava a oposição de membros das agremiações partidárias, assim como motivava a realização dealiançasentre antigos adversários.

Em 1861 houve uma eleição de deputados provinciais em São Paulo. OslíderesprovinciaisdoPartidoConservador,reunidosnoCentroConservador, tentaram impor candidaturas no $3^{\circ}$ distrito eleitoral da província. Porém, os chefesmunicipais do partidonãoacataram talingerência.Porconsequência, eles realizaram uma aliança com os liberais. Leia-se, pois, a seguinte informação publicada no Diário do Rio de Janeiro, em outubro do referido ano:

No $3^{\circ}$ círculo diversas influências conservadoras insurgiram-se contra a chapa

${ }^{41}$ A ORDEM, São Paulo, 30 de junho de 1862, n. 5, p. 4. 
organizada pelo centro conservador. Consta mesmo que há transação entre elas e diversos candidatos liberais, recomendados pelo centro liberal. A votação no colégio de Campinas, composto exclusivamente de eleitores liberais e que votou em diversos conservadores avulsos, bem indica a existência dessa transação. Estão à testa desta liga os Srs. Barão do Rio Claro, tenente-coronel Conceição, Dr. Pacheco Simões e Jordão, influências de Piracicaba, Limeira, Paranapanema, Tatuí, e Botucatu. Veremos o que surge deste caos. ${ }^{42}$

Dessa forma, a ausência de consulta aos correligionários para o lançamentodecandidaturasà CâmaradosDeputadoseraumelementointrínseco aos partidos Conservador e Liberal. A definição unilateral de candidaturas, contudo, despertavadistintasreações.Noaludidoepisódiodahistóriaeleitoralpaulista, verifica-seainconformidadedoscorreligionáriosconservadores. Entretanto, as candidaturas de Zacarias de Góis a deputado geral pelo Paraná não encontraram obstáculos para serem homologadas.

Cabe salientar, por outro lado, que a campanha para a eleição de um políticoadventícioeramarcada pelastentativasdecooptarseusantigoscontendores.Mais precisamente,competeapresentarevidências dequeos políticos não oriundos do Paraná precisavam estabelecer alianças com os chefes partidários provinciais. Em 1869, ao discorrer sobre a reeleição de Zacarias de Góis a deputado geral pelo Paraná, o bacharel conservador Manuel EufrásioCorreia (1839-1888) salientou queesseindivíduoarticulara a obtenção do apoio de um antigo desafeto político - o negociante ervateiro Manoel Antônio Guimarães (1813-1893). No contexto da inserção de Zacarias na dinâmica eleitoral do Paraná, Guimarães era a principal liderança do Partido Conservador na província:

E o que precisa saber é que o Sr. Zacarias, quando depois de sua preconizada presidência viu-se sem apoio em parte alguma, receoso de ver as portas da câmara temporária cerradas ainda, recomendado com força pelogoverno, acon-

42 DIÁRIO DO RIO DE JANEIRO, Rio de Janeiro, 21 de outubro de 1861, p. 2. 
selhavaumaaliançacomocomendadorGuimarães,que, apensardefulminado e posto à margem, foi acariciado para proteger a eleição de S. Ex. ${ }^{43}$

Dessaforma, a dependênciaemrelaçãoàinfluênciaeleitoraldosdirigentes partidários das províncias era um fator que atenuava, mesmo circunstancialmente,oconflitoentreesses dirigenteselideranças partidáriasnacionais.

Trata-se de evidenciar, por consequência, a interferência de um liberal não originário do Paraná na eleição para a Câmara dos Deputados ocorrida nessa província, em 1862. Para tanto, cumpre demonstrar que, no início dos anos 1860, não era incomum a interferência de lideranças nacionais dos partidos nos processos de definição de candidaturas a deputado geral. $\mathrm{Ou}$ seja,erarotineiraainterferência dessasliderançasnasdecisões dosdiretórios provinciais dos partidos. Em seguida, cabe realizar a análise de uma carta enviada ao Diário do Rio de Janeiro pelo citado Teófilo Benedito Otoni. Ele era uma antiga liderança nacional do Partido Liberal e exerceu mandato de senador por sua província de origem, Minas Gerais, de 1864 a 1869. No contexto da reeleição de Zacarias à Câmara dos Deputados pelo Paraná, Otoni desempenhava mandato de deputado geral. ${ }^{44}$

Assim, neste estágio do artigo é realizado o estudo sobre a missiva que Teófilo Ottoni endereçou a um órgão da imprensa carioca a respeito de sua interferência em uma eleição ocorrida no Paraná, em 1862. Nessa carta, ele defendeu que a reeleição de Zacarias não encontrou resistências junto aos liberais paranaenses.

Nessa oportunidade, o lançamento da candidatura de Zacarias à vaga dedeputadogeral pelo Paranáinviabilizouolançamentodecandidaturasno Partido Liberal e no Partido Conservador do Paraná. Zacarias, portanto, foi o único candidato a uma vaga de deputado geral por essa província. Nessa ocasião, o ex-presidente do Conselho de Ministros foi eleito deputado geral com 126 sufrágios. ${ }^{45}$

43 DEZENOVE DE DEZEMBRO, Curitiba, 27 de outubro de 1869, n. 1040, p. 3. Grifos no original.

44 Acerca da trajetória e ideias políticas de Teófilo Otoni, ver CHAGAS, Paulo Pinheiro (Org.). Teófilo Otoni. Brasília: Edição da Câmara dos Deputados, 1979.

45 JORNAL DO COMMERCIO, Rio de Janeiro, 04 de agosto de 1862, n. 214, p. 1. 
Dessa forma, o liberal Jesuíno Marcondes, adversário de Zacarias no pleito de 1861, tornou-se um apoiador da reeleição dessebacharel,em 1862. Marcondes, portanto, inibiu suas próprias pretensões eleitorais para viabilizar a vitória de Zacarias naquela eleição. Assim, a orientação emanada do diretório nacional do Partido Liberal impeliu Marcondes atuar como aliado de Zacarias.Porém, tal aliança foi efêmera, visto que se desfezapóso período eleitoral, conforme salientado na presente seção do artigo.

Outras lideranças liberais do Paraná, a exemplo dos bacharéis Laurindo de Brito (1828-1885) e o citado Manuel Alves de Araújo, também não combateram a candidatura de Zacarias. Nesse quadro, a missiva de Otoni veiculadanoDiáriodoRiodeJaneiroevidenciaqueaintegraçãodeZacariasao Partido Liberal do Paraná decorreu de um acordo entre os chefes nacionais e provinciais da agremiação:

O fraseado da correspondência do Paraná, publicada no seu jornal de hoje, pode fazer supor que o brioso partido liberal daquela província hesitasse em conferir seus votos ao Exmo. Sr. conselheiro Zacarias de Góis e Vasconcelos, e que só o fizesse mediante minha intervenção. Não há o menor fundamento para tal suposição. É certo que tive a honra de escrever aos meus amigos do Paraná dando-lhesconhecimentodomododigno, porque secomportara para com o partido liberal, o Sr. Conselheiro Zacarias na organização do ministério de 24 de maio, mas sua Exa. teve conhecimento da pronta resposta que deram antes de se entenderem, por exemplo, os Srs. Laurindo Abelardo de Brito e Dr. Manuel Alves de Araújo, aderindo francamente a sua candidatura. Quanto ao Sr. Jesuíno Marcondes de Oliveira e Sá, que só recebeu a correspondência dos seus amigos às vésperas da eleição, sabem muitas pessoas que em Sorocaba, onde se achava quando se organizou o ministério de 24 de maio, o Sr. Dr. Marcondes foi o primeiro a declarar, não só que se não apresentaria candidato, como também que entendia deverem os liberais votar unanimemente no presidente dogabinete de 24 de maio. Foiesta a vozuníssona dos paranaenses liberais. Honra Ihes seja feita. S. C. -5 de agosto de 1862 . T. B. Otoni. ${ }^{46}$

Em verdade, a carta de Teófilo Otoni consistia em uma réplica a um texto do correspondente do Diário do Rio de Janeiro em Curitiba. Para o correspondente, a vitória de Zacarias a deputado geral pelo Paraná derivava,

46 DIÁRIO DO RIO DE JANEIRO, Rio de Janeiro, 06 de agosto de 1862, n. 215, p. 1. 
sobretudo, da influência que Otoni teria exercido naquele pleito. A partir da análise dessa missiva, verifica-sequeos conservadores eosliberais doParaná não se mobilizaram para lançar outros candidatos na eleição para a Câmara dos Deputados, em 1862. Ou seja, a candidatura de Zacarias não encontrou resistências junto aos líderes do Partido Liberal do Paraná, bem como não encontrou oponentes no Partido Conservador:

O Sr. Conselheiro Zacarias de Góis e Vasconcelos, ex-presidente do Gabinete de 24 de Maio, acaba de ser reeleito deputado pela província do Paraná. S. Ex. obteve os votos que todos os eleitores, menos quatro. Podemos exprimir-nos por esta forma, por que o Colégio de Guarapuava, único que falta é em sua totalidade favorável à candidatura de $\mathrm{S}$. Ex. Este resultado é tão honroso para o Sr. Conselheiro Zacarias, como para a província do Paraná. É uma prova solene de adesão aos princípios proclamados, e ao procedimento observado por S. Ex. no desempenho de suas funções parlamentares. Só ontem nos veio às mãos à carta do nosso correspondente, datada de 24 passado. Diz o nosso correspondente:"A mais importante notícia que tenho a dar-lhes das ocorrências da quinzena é a eleição unânime do conselheiro Zacarias nos colégios da capital, Castro e Paranaguá. S. Ex. foi votado por todos os eleitores, menos quatro de Antonina que votaram no Dr. Manuel Alves de Araújo, cujo irmão, o comendador Antônio Alves, se tivesse chegado mais cedo, teria impedido essa excrecência na unanimidade. [...] Os eleitores do Príncipe, mesmo aquelesquepareciammais difíceisdecondescender,mostravam-semuitodesejosos do triunfo do ex-presidente do conselho. Em uma das passadas missivas Ihe disseque esperava-sequeoDr.Jesuíno [Marcondes] obtivesse de seus amigos dedicados a votação unânime, a ele talvez deva-se alguma coisa do resultado obtido, porém é certo que ao Sr. Ottoni deve-se tudo, segundo ouvi dos próprios eleitores". ${ }^{\prime 7}$

Ao mesmo tempo, a eleição de Zacarias foi apoiada pelo presidente do gabinete ministerial, o Marquês de Olinda. Em um sentido amplo, a informaçãotranscritaaseguir, aqualfoipublicadanojornalCommerciodoParaná, evidencia que a imposição de candidaturas não era realizada somente pelos gestores nacionais dos partidos monárquicos. Antes, os ministros também intervinham para garantir a eleição de seus aliados. Leia-se, pois, as considerações do correspondente do Commercio do Paraná:

47 DIÁRIO DO RIO DE JANEIRO, Rio de Janeiro, 05 de agosto de 1862, p. 1. 
Reeleição - O Conselheiro Zacarias foi reeleito pela totalidade dos eleitores que concorreram às urnas, à exceção de quatro votos, chamados de consciência que recaíram no ilustrado Sr. Manuel Alves de Araújo. O triunfo do Sr. Zacarias é uma prova da influência do Sr.Teophilo Ottoni, que o recomendou ao partido liberal com o maior empenho. Dizem também que houve cartas do Sr. presidente do Conselho fazendo as mesmas recomendações; eu o creio, à vistadomomentoqueseoperamláentreosmorcegos, porqueestessóseabalam pelo impulso que vem de cima. ${ }^{48}$

Por outro lado, nota-se que, mesmo sem o consentimento dos chefes partidários, alguns eleitores liberais do município de Antonina, situado na região litorânea, apoiaram a candidatura do bacharel paranaense Manuel Alves de Araújo. Nesse contexto, o jornal A Ordem, que tinha entre os seus principais redatores o citado Manuel Eufrásio Correia, criticou a eleição de Zacarias a deputado geral pelo Paraná. Nesse âmbito, o articulista do periódico salientou que o apoio obtido por Manuel de Araújo demonstrava a oposição ao nome de Zacarias no Paraná. Essa oposição, contudo, não era realizadapelaslideranças partidárias:"Constaquealgumasinfluênciaslocais sustentam a candidatura do Sr. conselheiro [Zacarias], e consta também que umnúmerodeeleitoresliberaisopõe-sefortementeasuareeleiçãoeaceitam a [candidatura] de Manuel Alves de Araújo".49

Assim, a influência do gabinete ministerial e de lideranças locais, no Paraná do início dos anos 1860, não era suficiente para impedir a eclosão de um descontentamento quanto à questão da imposição de candidaturas. Todavia, o apoio do gabinete ao projeto eleitoral de Zacarias tornava previsível a sua eleição. Conforme o redator de A Ordem, "O Sr. Zacarias será reeleito se o cavalheiro que o substituiu [na presidência do Conselho de Ministros] tomar a si conservar-Ihe [sic] a cadeira na Câmara temporária".50

De acordo com o articulista do jornal, o fato de Zacarias não ter adversários no pleito de 1862 evidenciava que os políticos paranaenses (con-

\footnotetext{
48 COMMERCIO DO PARANÁ, Paranaguá, 09 de agosto de 1862, n. 5, p. 4. Grifo no original.

49 A ORDEM, São Paulo, 28 de julho de 1862, n. 9, p. 2.

50 Loc. Cit.
} 
servadoreseliberais) perceberam quenãotinham condições deenfrentaros influentes políticosqueapoiavamoex-presidentedoConselhodeMinistros.

No início dessa eleição, houve uma movimentação dos conservadores para combater a candidatura de Zacarias. Todavia, essa movimentação rapidamente malogrou. A transcrição de um excerto de um texto do correspondente do Correio Mercantil evidencia a ocorrência dessa frustrada iniciativa. Datado de junho de 1862, esse texto contém indícios de que a debilidade da organização interna do Partido Conservador paranaense impediu, naquele momento, a existência uma oposição consistente na província:

Os homens que se intitulam ordeiros, tristes e abatidos com a notícia da subida do ministério de 24 de maio, tomaram novo gás de esperança com a entrada do dia nove deste mês [de junho] da barca Felicidade, procedente do Rio de Janeiro, portadora do Jornal do Commercio de 31 do mês passado, com a organização do actual ministério, sob a presidência do Sr. Marquez de Olinda. Congratularam-sereciprocamente[osconservadores],eosquequerempassar pela nata dos conservadores, possuídos de um prazer por tal notícia fizeram distribuir nesse dia pasquins com retratos alegóricos ao conselheiro Zacarias, convidando aos amigos deste para o seu funeral! Não serei eu quem diga, e nem preciso, provar, que essa gente que se arroga o pomposo título de conservador não passa de uma pequena facção que nenhum princípio defende, e que, aspirando ao poder apenas para locupletar-se, jamais a desonestidade dos meios que emprega a faz arrepiar carreira. Começam a trabalhar contra a reeleição do conselheiroZacarias, e para isto procura-se indispor a presidência comoseleitores destecírculo, mostrando-seatéaorganização de suplentes do juízomunicipalcomnomesinteiramentealheiosaocírculoaquepertencemos eleitores.Bem compreendoquea intrigaéa personagem quetemaseucargoo primeiro papel do desempenho. É absurdo querer plantar absurdos. Otempo é só de bela vegetação intelectual; mesmo assim não me sinto com força suficiente para precaver a cilada de certos politicões [sic] de aldeia. ${ }^{51}$

Adespeito dessamanifestação,osconservadores eximiram-sedelançar candidato à eleição para a Câmara dos Deputados, ocorrida em julho de 1862. Ou seja, os chefes da agremiação no Paraná não se dispuseram ao embatecomumcandidatoapoiadopelogabineteministerial.Aomesmotempo, a escusa de uma das lideranças partidárias da província, o liberal Manuel

51 CORREIO MERCANTIL, Rio de Janeiro, 29 de junho de 1862, n. 178, p. 1. Grifos no original. 
Alves de Araújo, em viabilizar a sua própria candidatura teria favorecido a homologação do nome de Zacarias.

A omissão daquela liderança frente à influência de Zacarias foi admoestada peloarticulista de AOrdem.Segundo o redator do periódico, Manuel de Araújo esteve na iminência de ser homologado candidato a deputado geral. Porém, a dissolução do gabinete no dia 30 de maio de 1862 promoveu rápida mudança no cenário eleitoral paranaense. Em resumo, o excerto reproduzido a seguir concentra informações acerca da neutralização de ambições políticas de um personagem de elite provincial ante a pretensão eleitoral de antigo membro do gabinete:

Cheia de embaraços se apresentava a reeleição do Sr. Conselheiro Zacarias. Os espíritos calmos não podiam formar um juízo seguro, porque tudo parecia envolto em um negro manto, ainda nas vésperas não se podia afirmar qual seria o eleito. Os Drs. José Mathias Ferreira de Abreu [conservador] e Jesuíno Marcondes de Oliveira e Sá [liberal], que tinham pleiteado a eleição, não contra o Sr. conselheiro, mas contra uma administração, que, cega de ambições e almejando ganhar as promessas que lhe tinham feito, envidou todos os meios a seu alcance, ainda os mais revoltantes e mais baixos, para galardoar aspretensões deseusapaniguados, nãoseapresentaram denovonocampoda luta porque não poderiam vencer contra a bruteza força. Restavam, porém, outrosquecombateramenergicamenteaspretensõesdosatuaisrepresentantes do Paraná, e entre eles aparece o Sr. Dr. Manuel Alves de Araújo como o mais competenteparafazercomqueaprovínciativesseaomenosumrepresentante legítimo. Corria como certo que, à vista das declarações de alguns eleitores influentes, que s. s. seria o substituto do ex-presidente do ministério surpresa. Um mau fado, porém, parece dominar os destinos do Paraná, a quem não é lícito alimentar uma esperança justa! S. s. deixou correr as coisas sem se lembrar que os interesses de sua província vão piorando dia a dia. Dos eleitores legítimos, dosverdadeirosrepresentantes dovotopopular,muitosdeixaramde comparecer, protestandoassimcontra aquelesque, pormerofavor, iamconfiar a representação da província a um homem que, em poucos anos, tem feito causa comum com todos os credos políticos. Eles também lembravam-se da luta de 60, e souberam ser coerentes com o seu primeiro ato, assim como o foramaqueles, quejungindo-seaocarrodirigido peloSr.conselheiro, seesqueceram que eram pensantes, e deixaram a outros o trabalho de pensar por eles. As folhas liberais não querendo do que disseram na ocasião em que a câmara temporáriafez-sepresentedosdiplomasdedeputadopeloParaná,entoaramhinos de glória à província em que o espírito público teve livre expansão; atribuem a reeleição a cartas de alguns indivíduos, sem atender que não houve quem se opusessefrancamente,apresentando-secandidatoàcadeiravagapelaascensão 
do conselheiro Zacarias ao ministério de 24 de Maio. ${ }^{52}$

Assim, para o articulista, a reeleição de Zacarias não permitiu aos chefes partidários do Paraná recuperaro controle sobrea gestão dos esquemas partidários perdido na campanha de 1861. Nessa ocasião, o resultado da eleição para deputado geral no Paraná evidenciou a capacidade do gabinete ministerial e do presidente da província interferirem para a vitória de seus candidatos. $O$ desinteresse dos eleitores em participar desse pleito foi, também, um indício de que a candidatura de Zacarias não obteve unânime aceitação na província. Em suma, a recusa dos chefes políticos provinciais em se confrontarem com um adventício respaldado por lideranças nacionais também gerou, segundooeditorialistadeAOrdem,oenfraquecimentodaautonomia do jogo partidário paranaense.

Os liberais paranaenses apoiaram a reeleição de Zacarias sem expressivas resistências. Em virtude desseapoio, esperavam obter determinados benefícios, tais comonomeações provinciais. No Paraná, nessecontexto, houve uma estreita relação entre as políticas de preenchimento de cargos comissionados e as articulações para o lançamento de candidatura parlamentar pelopartidosituacionista.Ademonstraçãodestaassertivaédesenvolvidano curso da presente seção. Em suma, em 1862 as lideranças liberais do Paraná atuaram para aplacar resistências à candidatura do ex-presidente do ConseIho de Ministros. Para demonstrar tal afirmação, compete atentar à seguinte informação apresentada pelo correspondente do Diário do Rio de Janeiro:

A eleição de 20 de Julho vai, segundo corre, levar o conselheiro Zacarias à câmara temporária, pois a sua candidatura é bem olhada quase geralmente; sendo que apenas no Príncipe se desconfia de divergência. Assim mesmo o Dr. JesuínoMarcondespode,ecreioquefaráalgumacoisaem proldoex-presidente do conselho. De Guarapuava vi uma carta ao major Luiz Gomes, membro da assembleia provincial, em que se diz haver a melhor disposição à respeito do conselheiro. ${ }^{53}$

52 A ORDEM, São Paulo, 18 de agosto de 1862, n. 12, p. 3. Grifos no original.

53 DIÁRIO DO RIO DE JANEIRO, Rio de Janeiro, 12 de julho de 1862, p. 1. 
No Colégio Eleitoral de Paranaguá, a eleição a deputado geral de 1862 foi marcada pela ausência de eleitores. Esse fato foi salientado pelo jornal Commercio do Paraná, em sua edição de 26 de julho do referido ano:

No dia 20 do corrente, reunindo-se o colégio eleitoral desta cidade para a votação do novo deputado que tem de preencher a vaga deixada pelo Snr. ConseIheiroZacarias deu em resultado obter estemesmoSnr.26votos, númeroigual de cédulas que entraram na urna. Deixarão de comparecer quatorze eleitores, por motivos que ignoramos ${ }^{54}$.

Por seu turno, o redator do jornal conservador A Ordem salientou que a ausência devotantesnessa eleiçãoera uma ação de protesto contraaimposição da reeleição de Zacarias.

Esta alternativa de opiniões, estas combinações políticas em que S. Exc. ${ }^{a}$ [Zacarias de Góis] parecia entrar por mero brinco, fizeram com que alguns de seus mandantes, duvidandodasinceridadedesuascrençasevendoquenãopodiam combate contra aqueles que não tinham recebido voto popular, deixassem de comparecer ao colégio eleitoral. Muitos deles se opunham a essa reeleição, e cônsciosdequeopartidooficialdoParanánãodeixariademostraraoBrasil,que para eles a política resume-se ao Eu, limitaram-se a protestar com o seu não comparecimento, contra o silêncio de uma e a coerência de outros. ${ }^{55}$

Nesse quadro, cabe analisar as informações presentes em uma carta do correspondentedoDiário doRiode JaneiroemParanaguá.Datadadeagosto de 1862, essa missiva contém evidências de que, em contrapartida ao fato de não terem exercido o controle sobre a definição de candidatura a deputado geral em 1862, os liberais paranaenses tinham o propósito de conservar seus cargos na administração provincial. Nessa época, o principal cargo por eles ambicionado era o de Juiz Municipal. Contudo, essas nomeações não ocorreram. Tal fato gerou a destituição do chefe do partido no litoral do Paraná. Leia-se, pois, as considerações do mencionado correspondente:

As nomeações ultimamente feitas pela presidência da província para suplen-

54 COMMERCIO DO PARANÁ, Paranaguá, 26 de julho de 1862, n. 30, p. 1.

55 A ORDEM, São Paulo, 18 de agosto de 1862, n. 12, p. 2. Grifos no original. 
tes do juiz municipal deste termo [de Paranaguá], trouxeram desconfiança a alguns dos membros do lado liberal de que o chefe deste grupo havia traído omesmo, econseguintementetendoos seus membros prestadoà presidência um importante serviço, qual foi o esforçarem-se pela reeleição do conselheiro Zacarias, contavam quea mesma presidência não esqueceria o nome dos mais habilitados para a formação da lista dos suplentes do juiz municipal, durante o quatriênio que começa a correr. Dizem, portanto, os desgostosos que S. Ex. jogoucompãodedoisbicos, porqueasnomeaçõessurgiramàluzdepoisdeconsumada a reeleição do conselheiro Zacarias. Daqui pode-se concluir qual o desapontamentodaquelesqueesperavamsernomeadossuplentes, tantomais quando contavam com a sinceridade de seu chefe para que os recomendasse ao governo da província. No rol dos nomeados aparecem três saquaremas e três liberais: já se vê que não houve tino e menos gratidão da parte do Sr. Dr. Nogueira para a escolha de que me ocupo. Uma fracção dos descontentes reuniu-se na chácara do Ypiranga, para tratar de negócio sério a respeito, e apesar de ter sido convidado o chefe liberal para assistir a discussão, não se dignou aceitar o convite [...]. Corre que nessa reunião vão os liberais tratar de eleger um novo chefe, visto como as nomeações de que tenho falado depõe muito contra o atual chefe pelo crime de traição. ${ }^{56}$

Após a sua reeleição pelo Paraná, Zacarias não encampou demandas econômicas propugnadas pelos seus antigos correligionários do Paraná. Compete salientar o fato de que a sua decisão não pleitear a reeleição a deputado geral pelo Paraná, em 1863, foi percebida na imprensa como um acontecimento propícioà recuperação da influência dos gestores do Partido Liberal naquela província. Segundo o articulista do Correio Mercantil,

O Sr. Zacharias não se apresentando candidato [a deputado geral, em 1863] por esta província deu mais uma prova de amor ao progresso e harmonia do Paraná, a quem quer como se fosse sua terra natal. Os nomes dos Srs. Dr. Laurindo [Abelardo de Brito] e Jesuíno [Marcondes] são por sem dúvida os mais prestigiosos e dignos do sufrágio do povo paranaense. [...] tudo faz crer que as eleições correrão nesta província tranquilas e livres como deseja o governo. ${ }^{57}$

Nesse sentido, tal decisão de Zacarias evitou que os antigos chefes liberais da província cerceassem novamente as suas próprias pretensões eleito-

56 DIÁRIO DO RIO DE JANEIRO, Rio de Janeiro, 30 de agosto de 1862, p. 2.

57 CORREIO MERCANTIL, Rio de Janeiro, 12 de julho de 1863, n. 190, p. 1. 
rais. Assim, nota-se que a interferência de Zacarias e dos líderes nacionais do PartidoLiberal na gestão dos esquemas eleitorais dessaagremiaçãonoParanágeroudescontentamentosporpartedoschefesprovinciaisdaagremiação. Contudo, esses chefes não seeximiram de oficializar o apoioàquele bacharel ante a determinação do Centro Diretor do partido.

UmindíciododistanciamentoentreZacariaseoslíderesparanaensesdo PartidoLiberaléevidenciadoemumtextodoarticulistadoCorreioMercantil, datado de janeiro de 1867. Nesse texto, ele mencionou as críticas endereçadas por Zacarias à atuação de Jesuíno Marcondes no posto de ministro da Agricultura, nos anos de 1864 e 1865. As considerações transcritas a seguir foram produzidas no contexto em que o Partido Liberal discutia a definição das suas candidaturas a deputado geral pelo Paraná:

O Sr. Polydoro [Burlamaque, então presidente do Paraná] declara, segundo me informam, que só tem compromissos com o Dr. Laurindo, batendo por isso outro qualquer candidato que não sejam ele e seu companheiro conselheiro Marcondes. O que não sei é como fazer isto o delegado do gabinete presidido pelo conselheiroZacarias, cujos discursos sobre o Paraná ea respeito do ministro da agricultura [Jesuíno Marcondes] do ministério de 10 de agosto correm por aqui e mão em mão. ${ }^{58}$

De fato, na edição do Correio Mercantil de 10 de julho de 1867, Marcondes fora situado como integrante do grupo de deputados gerais que se opunham ao gabinete presidido por Zacarias. ${ }^{59}$ Nesse quadro, verifica-se a natureza artificial da aliança entre chefes liberais do Paraná e indivíduos de maior projeção do cenário político imperial. Essa aliança, em verdade, resultado da prática da imposição de candidaturas por chefes nacionais do Partido Liberal. O término do mandato de Zacarias como deputado geral pelo Paraná consolidou o distanciamento desse bacharel em relação aos políticos paranaenses que, tais como Jesuíno Marcondes, foram impelidos por dirigentes partidários nacionais a apoiá-lo no pleito de 1862.

58 CORREIO MERCANTIL, Rio de Janeiro, 15 de janeiro de 1867, n. 15, p. 1.

59 CORREIO MERCANTIL, Rio de Janeiro, 10 de julho de 1867, n. 189, p. 3. 
Dessa forma, a eleição de Zacarias a deputado geral pelo $3^{\circ}$ círculo eleitoral da província da Bahia, em dezembro de 1863, encerrou o envolvimento desse bacharel na vida partidária do Paraná. ${ }^{60}$ Portanto, esse encerramento foi entendido na província como elemento capital para a retomada da autonomia das antigas lideranças do Partido Liberal paranaense.

\section{Considerações finais}

As eleições de Zacarias de Góis a deputado geral pelo Paraná, em 1861 e 1862, aconteceramnoperíodoanterioràreorganizaçãodomodelodegestão dos diretórios nacionais e provinciais dos partidos Conservador e Liberal. Dessemodo,osepisódiosdasaludidaseleiçõesconsistememindíciosdeque, anteriormente àquela reorganização, eram menos precisas as regras atinentes ao relacionamento entre as instâncias dos partidos.

No começo dos anos 1860, a incipiência dessas regras instaurava uma situaçãona qualaslideranças nacionais dos partidosmonárquicos possuíama prerrogativa de indicar, de forma unilateral, candidatos às eleições a Câmara dos Deputados. Essa prerrogativa minava, ainda que momentaneamente, a influência de membros da elite provincial sobre a gestão do Partido Liberal no Paraná. De outra parte, nesse contexto havia interferência do gabinete ministerial para viabilizar o sucesso eleitoral de seus aliados.Tal interferência era também um fator de restrição dos poderes políticos dos integrantes da eliteparanaense.Emsíntese, aautonomiadosgestoresprovinciaisdoPartido Liberal foi enfraquecida, no início daquela década, em decorrência dos desígnios eleitorais dos líderes nacionais da agremiação.

Nesse quadro, olançamento de um candidato de projeção nacional pelos liberais tinha efeitos negativos sobre a atividade política do Partido Conservador. O principal efeito negativo era impelir a oposição a abdicar da pretensão de concorrerà eleição. Dessa maneira, os mencionados episódios da vida política do Paraná evidenciam os impactos da modelo de gestão dos partidosmonárquicossobreosresultadoseleitorais.Maisprecisamente, afalta de regras consistentes acerca da relação entre o diretório provincial e o

60 DIÁRIO DO RIO DE JANEIRO, Rio de Janeiro, 24 de dezembro de 1863, n. 354, p. 1. 
diretório nacional do Partido Liberal permitiu a imposição, por gestores nacionais da agremiação, da candidatura de Zacarias de Góis de Vasconcelos em 1862. Ao mesmo tempo, a ausência de uma sólida organização interna doPartidoConservadorparanaenseimpediuqueessaagremiaçãosustentasseuma candidatura deoposiçãoe mobilizasseos seus correligionários parao êxito dessa iniciativa.

Nesse contexto, uma das pretensões das lideranças nacionais dos partidosmonárquicoseraviabilizarapermanênciadeseusaliadoseminstituições como a Câmara dos Deputados. Ou seja, o objetivo central dessas lideranças era manter seus aliados politicamente ativos. Para tanto, eram adotados expedientes como inserir tais aliados na vida eleitoral de províncias dais quais não eram originários. Essa inserção, porém, não se desdobrava na concretização de uma aliança entre o político não oriundo da província e os chefes partidários paranaenses. $O$ apoio conferido por esses chefes ao adventício era, pois, uma evidência da autoridade dos dirigentes nacionais da agremiação sobre a definição de candidaturas à Câmara dos Deputados.

\section{Fontes documentais}

Os periódicos mencionados a seguir estão disponíveis para consulta no sítio da Hemeroteca Digital Brasileira: http://bndigital.bn.gov.br/hemeroteca-digital/

A ACTUALIDADE (RJ)

A ORDEM (SP)

CONSTITUCIONAL (RJ)

CORREIO MERCANTIL (RJ)

DEZENOVE DE DEZEMBRO (PR)

DIÁRIO DO RIO DE JANEIRO (RJ)

GAZETA DE NOTÍCIAS (RJ)

JORNAL DO COMMERCIO (RJ)

Operiódicomencionadoaseguirestádisponível paraconsultanoarquivodo Instituto Histórico e Geográfico de Paranaguá 
COMMERCIO DO PARANÁ (PR)

\section{Bibliografia}

ALVES, Alessandro Cavassin. A Província do Paraná (1853-1889): a classe política, a parentela no Governo. Tese (Doutorado em Sociologia). Setor de Ciências Humanas, Letras e Artes, Universidade Federal do Paraná, Curitiba, 2014.

AMARAL, Roberto; BONAVIDES, Paulo. Textos políticos da História do Brasil. Volume II. 3. ed. Brasília: Senado Federal, 2002, p. 456-470.

BANDECCHI,PedroBrasil.BasesdaUniãoConservadoraeosEstatutosdoGrêmio PaulistanoeosprimórdiosdomovimentorepublicanoemSãoPaulo.Revistadolnstituto de Estudos Brasileiros, São Paulo, n. 14, 1973, p. 149-158.

CARDOSO,JaymeAntônio.A populaçãovotantedeCuritiba(1853-1881).Dissertação (Mestrado em História). Setor de Ciências Humanas, Letras e Artes, Universidade Federal do Paraná, Curitiba, 1974.

.Essaid'utilisationdeslisteselectoralesdansl'étudedelapopulationduParaná (Brésil) vers 1870.Tese (Doutorado em História).École des Hautes Études en Sciences Sociales, Paris, 1977.

CARVALHO, José Murilo de. A construção da ordem: a elite política imperial \&Teatro das sombras: a política imperial.3.ed. Rio de Janeiro: Civilização Brasileira, 2007.

CAVALCANTI, Themístocles Brandão. O voto distrital no Brasil. Rio de Janeiro: Editora da Fundação Getúlio Vargas, 1975.

CHACON,Vamireh.Históriadospartidosbrasileiros.Brasília:EditoradaUnB,1981.

CHAGAS, Paulo Pinheiro (Org.). Teófilo Otoni. Brasília: Edição da Câmara dos Deputados, 1979.

COSTA, Emília Viotti da. Da Monarquia à República:momentos decisivos. 8. ed. São Paulo: Ed. da Unesp, 2007.

DANTAS, Mônica Duarte. Partidos, liberalismo e poder pessoal: a política no Império do Brasil. Um comentário ao artigo de Jeffrey Needell, Formação dos partidos políticos no Brasil da Regência à Conciliação, 18311857. Almanack Braziliense, São Paulo, n. 10, 2009, p. 40-47.

DOLHNIKOFF, Miriam. O pacto imperial: origens do federalismo no Brasil. São Paulo: Globo, 2005. 
ESTEFANES, Bruno Fabris. Conciliar o Império: Honório Hermeto de Carneiro Leão, os partidos e a política de Conciliação no Brasil monárquico (1842-1856). Dissertação (Mestrado em História Social). Faculdade de Filosofia, Letras e Ciências Humanas, Universidade de São Paulo, São Paulo, 2010.

FAORO, Raymundo.Osdonosdopoder:formaçãodopatronatopolíticobrasileiro. 8. Ed. São Paulo: Globo, 1989.

FARIA,VanessaSilvade.OprocessodequalificaçãodevotantesnoBrasillmpério: perfil da população votante no distrito sede de Juiz de Fora, Minas Gerais (1872-1876). Dissertação (Mestrado em História). Instituto de Ciências Humanas e Sociais, Universidade Federal de Ouro Preto, Mariana, 2011.

FERRAZ, Sérgio Eduardo. O Império revisitado: Poder Moderador, Câmara dos Deputados e instabilidade ministerial (1840-1889). Tese (Doutorado em Ciência Política). Faculdade de Filosofia, Letras e Ciências Humanas, Universidade de São Paulo, São Paulo, 2012.

FRANCO,AfonsoArinosdeMelo.HistóriaeteoriadospartidospolíticosnoBrasil. São Paulo: Alfa-Ômega, 1974.

FREITAS, Ana Paula Ribeiro. Minas e a Política Imperial: reformas eleitorais e representação política no Parlamento brasileiro (1853-1863). Tese (Doutorado em História Social). Faculdade de Filosofia, Letras e Ciências Humanas, Universidade de São Paulo, São Paulo, 2015.

GOUVÊA, Maria de Fátima Silva. O Império das províncias: Rio de Janeiro, 1822-1889. Rio de Janeiro: Civilização Brasileira, 2008.

GRAHAM,Richard.ClientelismoepolíticanoBrasildoséculoXIX.RiodeJaneiro: Editora da Universidade Federal do Rio de Janeiro, 1997.

HÖRNER, Erik. Partir, fazer e seguir: apontamentos sobre a formação dos partidos e participação política no Brasil da primeira metade do século In: XIX. MARSON, Isabel Andrade; OLIVEIRA, Cecília Helena Sallesde.Monarquia,LiberalismoeNegóciosnoBrasil:1790-1860.SãoPaulo: Edusp, 2013, p. 213-240.

KINZO,MariaDalvaGil.RepresentaçãopolíticaesistemaeleitoralnoBrasil.São Paulo: Edições Símbolo, 1980.

LIMONGI, Fernando. Revisitando as eleições do Segundo Reinado: manipulação, fraude e violência. Lua Nova, São Paulo, n. 91, 2014, p. 51-113.

MARTINS, Maria Fernanda Vieira. A velha arte de governar: uma abordagem sobre elites políticas a partir do Conselho de Estado (1842-1889). Rio de 
Janeiro: Arquivo Nacional, 2007.

MATTOS, Ilmar Rohloff de. O tempo Saquarema. São Paulo: Hucitec, 1986.

MOREIRA, Gustavo Alves Cardoso. Uma família no Império do Brasil: os Cardoso de Itaguaí (um estudo sobre economia e poder). Dissertação (Mestrado em História). Instituto de Ciências Humanas e Filosofia, Universidade Federal Fluminense, Niterói, 2005.

MOSHER,JeffreyC.PoliticalStruggle,IdeologyandtheStateBuilding:Pernambuco and the construction of Brazil, 1817-1850. Lincoln: University of Nebraska Press, 2008.

. Political mobilization, party ideology, and lusophobia in nineteenth-centuryBrazil:Pernambuco, 1822-1850.HispanicAmericanHistorical Review, vol. 80, n. 4, 2000, p. 881-912.

MOTTA,RodrigoPattoSá.Introduçãoàhistóriadospartidospolíticosbrasileiros. Belo Horizonte: Editora da Universidade Federal de Minas Gerais, 1999.

NASCIMENTO, CarlaSilva do.OBarão deCotegipe ea crise dolmpério.Dissertação (Mestrado em História). Centro de Ciências Humanas e Sociais, Universidade Federal do Estado do Rio de Janeiro, Rio de Janeiro, 2012.

NEEDELL, Jeffrey D. Formação dos partidos brasileiros: questões de ideologia, rótulospartidários,liderançasepráticapolítica, 1831-1888.Almanack Braziliense, São Paulo, n. 10, 2009, p. 54-63.

. Formação dos partidos políticos no Brasil da Regência à Conciliação, 1831-1857. Almanack Braziliense, São Paulo, n. 10, 2009, p. 5-22.

.The party of order: the conservatives, the State, and slavery in the Brazilian monarchy. Stanford: Stanford University, 2006.

NICOLAU, Jairo. Eleições no Brasil: do Império aos dias atuais. Rio de Janeiro, Zahar, 2012.

NUNES, Neila Ferraz Moreira. A experiência eleitoral em Campos dos Goytacazes (1780-1889): frequência eleitoral e perfil da população votante. Dados, Rio de Janeiro, v. 46, n. 2, 2003, p. 311-343.

OLIVEIRA, Carlos Eduardo França de.Construtores do Império, defensores da província: São Paulo e Minas Gerais na formação do Estado Imperial e dos poderes locais, 1823-1834. Tese (Doutorado em História Social). Faculdade de Filosofia, Letras e Ciências Humanas, Universidade de São Paulo, São Paulo, 2014.

OLIVEIRA, Cecília Helena Salles (Org.). Zacarias de Góis e Vasconcelos. São 
Paulo: Editora 34, 2002.

PORTO, Walter Costa. O voto no Brasil: da Colônia à $6^{a}$ República. Rio de Janeiro: Topbooks, 2002.

RIBEIRO, Filipe Nicoletti. Império das incertezas: política e partidos nas décadas finais da monarquia brasileira (1868-1889). Dissertação (Mestrado em História Social). Faculdade de Filosofia, Letras e Ciências Humanas, Universidade de São Paulo, São Paulo, 2015.

ROETT, Riordan. Brazil: Politics in a Patrimonial Society. New York: Praeger Publichers, 1984.

SALLES, Ricardo. Notas de um debate: Comentários sobre o texto de Jeffrey Needell Formação dos partidos políticos no Brasil da Regência à Conciliação, 1831-1857. Almanack Braziliense, São Paulo, n. 10, 2009, p. 48-53.

VENÂNCIO FILHO, Alberto (Org.). Zacarias de Góis e Vasconcelos. Brasília: Edição da Câmara dos Deputados, 1979.

Recebido: 31/05/2016 - Aprovado: 05/06/2017 